5. ガ

\section{1 天然ガス開発の動向}

\section{1. 日本}

\section{1 探鉱 - 開発の概要}

昭和30年代半ば頃までの国産天然ガスは，一部の油 井の随伴ガスを除けば，すべて水溶性天然ガスで占め られていた。しかし，水溶性天然ガスの採取は地盤沈 下問題につながるとの危惧が表面化したために, 主産 地の新潟県内につついて千葉県下においても採取規制 が40年頃からはじまり，45年をピークとして生産は大 偪に減退の途を辿ることになった。

たまたま，30年代に入っての本格的な探鉱・開発促 進策（数次にわたる 5 ケ年計画）が効を奏して, 東北 裏日本一帯で構造性天然ガス鉱床が続々と発見される よらになり，40年代に入って生産が急増し，ようやく 本格的な生産体制が整えら机た。

国産天然ガスは，都市ガスのよらな燃料用途のほか 化学工業原料としての利用も急伸し, 東北裏日本执よ び千葉県下での大々的な化学会社の進出がみられた。

このように，天然ガス資源の評価は次第に高まって きたが，37年に建設された新潟一東京間約 $340 \mathrm{~km}$ の長 距離, 大容量パイプラィンによって, 天然ガスが東京
ス

都周辺の都市ガス原料として登場してからは, 都市ガ ス用として隔絶したメリットが認識されるようになっ た。

また，44年 2 月の閣議決定「硫黄酸化物に係る環境 基準について」の中で，天然ガスの探鉱・開発および 輸入の促進がとりあげられているように，公害対策の 決め手となるクリーンェネルギーとしての天然ガス需 要が増大し, 発電用然料として一挙に大量利用の時代 に突入した。

このような情勢に促されて主産地の東北襄日本さえ 天然ガス不足に呻吟する事態に立ち至り，国内資源の 開発促進はもらろん, 海外からの導入が真剣に検討さ れ，LNGとして大量の天然ガスの輸入が実現したの である。

水溶性天然ガスも, エネルギー不足時代を迎えて, 脚光を浴び，採取規制に対処する付随水の地下還元圧 入方式といら新技術が企業化されたことと相俟って再 開発の機運が訪れた。水溶性天然ガスは全国に広く分 布して扣り，その究極埋蔵量は 4,000 億 $\mathrm{m}^{3}$ と多いれ ており，わが国唯一の豊富なクリーンエネルギーであ る。

\section{2 天然ガスの開発と生産}

昭和 37 年以降, 天然ガスの生産は表5-1のと拈り で, 52 年の 27.8 億 $\mathrm{m}^{3}$ をピークとして漸減し, 57 年は 20.5 億 $\mathrm{m}^{3}$ となっている。生産量は 52 年には構造性ガス

表 5-1 天然ガス鉱床別・地域別・生産量の推移

(単位 百万 $\mathrm{m}^{3}$ )

\begin{tabular}{|c|c|c|c|c|c|c|c|c|c|c|c|c|c|c|c|}
\hline \multirow[b]{2}{*}{ 年度 } & \multirow{2}{*}{ 全生 } & \multirow{2}{*}{$\begin{array}{l}\text { 海域生産 } \\
\text { 量 (全生 } \\
\text { 産量の内 } \\
\text { 数) }\end{array}$} & \multicolumn{4}{|c|}{ 水溶性ガス } & \multicolumn{4}{|c|}{ 油田随伴ガス } & \multicolumn{3}{|c|}{ 構造性ガス } & \multirow{2}{*}{$\begin{array}{l}\text { 炭 } \\
\text { ガ }\end{array}$} & \multirow{2}{*}{$\begin{array}{l}\text { 田 } \\
\text { ス }\end{array}$} \\
\hline & & & 新潟 & 千葉 & その & 計 & 秋田 & 新潟 & $\begin{array}{l}\text { その } \\
\text { 他 }\end{array}$ & 計 & 新 潟 & $\begin{array}{l}\text { その } \\
\text { 他 }\end{array}$ & 計 & & \\
\hline 50 & 2,446 & - & 80 & 488 & 16 & 584 & 21 & 25 & 7 & 53 & 1,796 & 7 & 1,803 & 6 & \\
\hline 51 & 2,604 & 293 & 79 & 474 & 15 & 568 & 19 & 25 & 7 & 51 & 1,970 & 7 & 1,977 & 7 & \\
\hline 52 & 2,775 & 617 & 73 & 451 & 17 & 541 & 18 & 26 & 8 & 52 & 2,170 & 5 & 2,175 & 8 & \\
\hline 53 & 2,583 & 554 & 72 & 446 & 15 & 533 & 18 & 23 & 9 & 50 & 1,989 & 5 & 1,994 & 6 & \\
\hline 54 & 2,351 & 479 & 71 & 443 & 13 & 527 & 17 & 19 & 9 & 45 & 1,772 & 3 & 1,775 & 4 & \\
\hline 55 & 2,151 & 399 & 77 & 448 & 11 & 536 & 16 & 20 & 9 & 45 & 1,564 & 3 & 1,567 & 3 & \\
\hline 56 & 2,084 & 325 & 82 & 454 & 12 & 548 & 16 & 17 & 8 & 41 & 1,471 & 2 & 1,493 & 1 & \\
\hline 57 & 2,047 & - & 81 & 453 & 13 & 547 & 15 & 18 & 8 & 41 & 1,454 & 3 & 1,457 & 1 & \\
\hline
\end{tabular}


表 5-2 昭和57年天然ガス（鉱床別）生産量（昭和57年 1 月～12月）

(単位 $: 10^{3} \mathrm{~m}^{3}$ )

\begin{tabular}{|c|c|c|c|c|c|c|c|c|}
\hline 鉱床另 & & 水溶 形 & 油 溶 形 & $\begin{array}{c}\text { 遊 } \\
\text { (構 }^{\text {離 }} \text { 造) }\end{array}$ & 炭 田 & 計 & $\begin{array}{c}\text {. 前年比 } \\
(\%)\end{array}$ & $\begin{array}{c}\text { 構成比 } \\
(\%)\end{array}$ \\
\hline 北 海 & 道 & 676 & - & 1,433 & - & 2,109 & 79.4 & 0.10 \\
\hline 秋 & 田 & 4,328 & 14,921 & 1,256 & - & 20,505 & 96.6 & 1.00 \\
\hline 山 & 形 & - & 8,252 & - & - & 8,252 & 96.4 & 0.40 \\
\hline 福 & 島 & - & - & - & 1,299 & 1,299 & 88.7 & 0.06 \\
\hline 新 & 潟 & 81,427 & 18,229 & $1,454,930$ & - & $1,554,586$ & 96.5 & 75.93 \\
\hline 長 & 野 & 230 & - & 42 & - & 272 & 103.8 & 0.02 \\
\hline 千 & 葉 & 453,694 & - & - & - & 453,694 & 100.4 & 22.16 \\
\hline 東 & 京 & 198 & - & - & - & 198 & 99.5 & 0.01 \\
\hline 静 & 岡， & 21 & - & - & - & 21 & 36.8 & - \\
\hline 富 & 山 & 787 & - & - & - & 787 & 112.4 & 0.04 \\
\hline 宮 & 崎 & 5,716 & - & - & - & 5,716 & 120.0 & 0,28 \\
\hline 合 & 計 & 547,077 & 41,402 & $1,457,661$ & 1,299 & $2,047,439$ & 97.4 & 100.00 \\
\hline 構 成 比 & $\%)$ & 26.72 & 2.02 & 71.20 & 0.06 & 100.00 & & \\
\hline 前 年 比 & $\%)$ & 100.5 & 101.0 & 96.2 & 80.3 & 97.4 & & \\
\hline
\end{tabular}

資料：天然ガス鉱業会資料年報

表 5-3 昭和56年度わが国の主要ガス田の生産量

(単位: $10^{3} \mathrm{~m}^{3}$ )

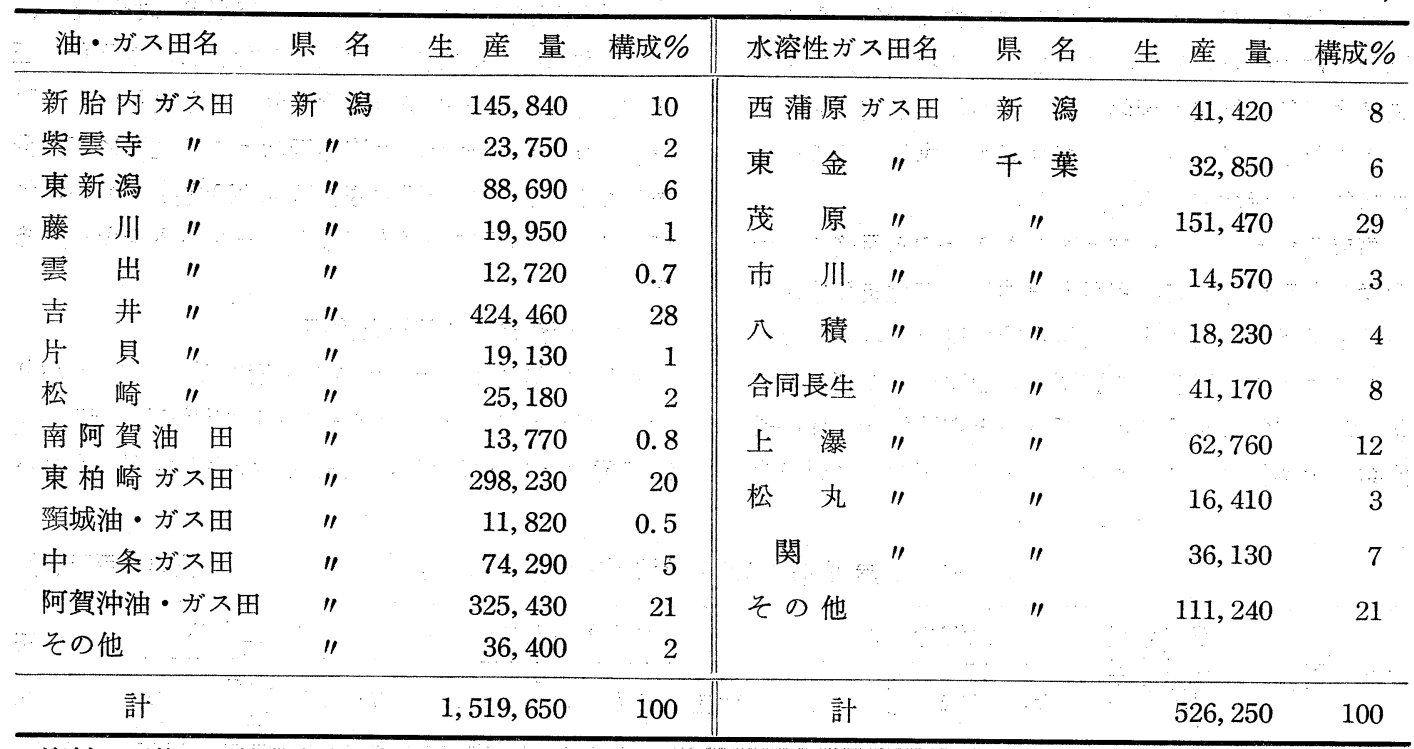

資料：天然ガス鉱業会資料年報

が全体の78\%；水溶性ガス19\%であったが，57年には 構造性ガスは71\%，水溶性ガスは $27 \%$ であった。全体 として漸減には構造性ガスの減産が大きく影響してい る。天然ガスの生産は, 秋田, 新潟県で全体の $77 \%$ で あるが (表 5-2, 表5-3 参照), 日本海沿岸地域は, “今 後も最も有望な地域とされており，積極的な探鉱・開 発が期待される。
一方，わが国初の大平洋側の常磐沖ガス田の開発む 着々と進められ，近く生産用プラットホームが建設さ れる。生産が開始されると日産 120 万 $\mathrm{m}^{3}$ の天然ガスが 採取される見通しである。新潟県阿賀沖北の開発につ いても採算検討が行われて扣り,陸城においては秋田, 新潟県で相当量の天然ガスが発見されているので，わ が国の天然ガスの埋蔵量は今後飛躍的に増加するもの 
と思われる。

すなわら，56年度陸域においては補助井11坑を含む 17 坑の試掘が行われ, そのらち成功井は 5 本, $30 \%$ の 確率である。海域は国の基礎試錐 1 坑を含む 7 坑が試
掘され，油・ガス徽が確認されたものは 2 坑である。 57 年度は陸域で補助井 8 坑を含む15坑が試掘され，ま た, 現在 (3月20日) 試掘中のものもあるが, 7 坑が 成功井である。

表 5-4 L N $\mathbf{N}$ G $の$ 輸 入 推 移

(単位: $1,000 t$ )

\begin{tabular}{|c|c|c|c|c|c|}
\hline & 合 計 & アラスカ & ブルネイ & アブダビ & インドネシア \\
\hline 昭和44年度 & 182 & 182 & - & $\therefore-$ & - \\
\hline " 45 " & 977 & 977 & - & - & - \\
\hline$" 46 "$ & 969 & 969 & - & - & - \\
\hline " $47 "$ & 1,068 & 872 & 196 & - & 一 \\
\hline$" 48 " \prime$ & 2,364 & 989 & 1,375 & - & 一 \\
\hline " 49 " & 3,777 & 961 & 2,816 & - & - \\
\hline " $50 "$ " & 5,005 & 1,017 & 3,988 & - & - \\
\hline " $51 "$ & 5,903 & 934 & 4,969 & - & - \\
\hline " $52 " \prime$ & 8,247 & 1,013 & 5,262 & 706 & 1,266 \\
\hline " 53 " & 11,685 & 958 & 5,297 & 1,185 & 4,245 \\
\hline " 54 " & 14,858 & 958 & 5,543 & 1,462 & 6,895 \\
\hline " 55 " & 16,965 & 872 & 5,419 & 2,001 & 8,674 \\
\hline " 56 " & 16,998 & 1,006 & 5,157 & 2,018 & 8,817 \\
\hline " 57 年 & 17,454 & 958 & 5,154 & 2,208 & 9,134 \\
\hline
\end{tabular}

資料：天然ガス鉱業会資料年報＼cjkstart注：57年は暦年とした

表 5-5 世界の L N G 取引きの実績

(単位: $1,000 t$ )

\begin{tabular}{|c|c|c|c|c|c|c|c|c|c|c|c|c|c|c|c|}
\hline route & 1966 & 1967 & 1968 & 1969 & 1970 & 1971 & 1972 & 1973 & 1974 & 1975 & 1976 & 1977 & 1978 & 1979 & 1980 \\
\hline $\begin{array}{l}\text { Algeria } \\
\text {-U.K. }\end{array}$ & 478 & 574 & 745 & 782 & 626 & 624 & 575 & 551 & 438 & 607 & 750 & 864 & 714 & 451 & 572 \\
\hline $\begin{array}{l}\text { Algeria } \\
\text {-France }\end{array}$ & 294 & 349 & 314 & 419 & 423 & 378 & 575 & 1,183 & 1,379 & 1,714 & 1,979 & 1,714 & 2,214 & 1,936 & 1,429 \\
\hline $\begin{array}{l}\text { Algeria } \\
\text {-U.S.A. }\end{array}$ & - & - & - & - & 15 & 56 & 46 & 78 & - & 94 & 195 & - & 714 & N.A. & 1,500 \\
\hline $\begin{array}{l}\text { Algeria } \\
\text {-Spain }\end{array}$ & - & - & - & - & - & - & - & - & 214 & 393 & 316 & $176^{\circ}$ & 929 & 455 & $\therefore \quad 857$ \\
\hline $\begin{array}{l}\text { Libya } \\
\text {-Italy }\end{array}$ & - & - & - & - & - & 22 & 983 & 1,356 & 1,269 & 1,357 & 1,929 & 1,786 & 1,786 & 1,457 & 1,072 \\
\hline $\begin{array}{l}\text { Libya } \\
\quad \text {-Spain }\end{array}$ & - & - & - & - & - & 284 & 461 & 588 & 431 & 643 & 824 & 879 & 786 & 862 & 572 \\
\hline $\begin{array}{l}\text { Alaska } \\
\text { 一日本 }\end{array}$ & - & - & - & 53 & 848 & 982 & 919 & 933 & 933 & 1,046 & 956 & 993 & 930 & 985 & 859 \\
\hline $\begin{array}{l}\text { Brunei } \\
\text { 一日本 }\end{array}$ & - & - & - & - & - & - & 33 & 1,014 & 2,489 & 3,514 & 4,836 & 5,395 & 5,265 & 5,414 & 5,550 \\
\hline $\begin{array}{l}\text { Abu } \\
\text { Dhabi } \\
\qquad \text {-日本 }\end{array}$ & - & - & - & - & - & - & - & - & - & - & - & 382 & 1,258 & 1,242 & 1,929 \\
\hline $\begin{array}{r}\text { Indonesia } \\
\text {-日本 }\end{array}$ & - & - & - & - & - & - & - & $\cdots-$ & - & - & - & 490 & 3,720 & 6,165 & 8,504 \\
\hline 計 & 772 & 923 & 1,059 & 1,254 & 1,912 & 2,350 & 3,592 & 5,708 & 7,153 & 9,368 & 11,785 & 12,679 & 18,316 & 18,967 & 22,844 \\
\hline
\end{tabular}

資料：OECD 石油統計75, A. G. A. Gas Facts 特よび日本貿易月報による。ガス化率 $1,400 \mathrm{~m}^{3} / \mathrm{t}$ 
(1) 操業中のプロジェクト

表 5-6.日本向け L N G プロジェクトー覧

\begin{tabular}{|c|c|c|c|c|c|c|c|}
\hline \multirow{2}{*}{ No. } & \multirow{2}{*}{$\begin{array}{l}\text { プロジェク } \\
\text { ト名 } \\
\text { (受入基地) }\end{array}$} & \multirow{2}{*}{ 主要関係者 } & \multirow{2}{*}{$\begin{array}{l}\text { 輸 入 量 } \\
\text { (万t } \mathrm{t} / \text { 年) }\end{array}$} & \multirow{2}{*}{\begin{tabular}{|} 
輸入時期 \\
および期間
\end{tabular}} & \multirow{2}{*}{\multicolumn{2}{|c|}{$\begin{array}{ll}\text { 送 } & \text { 関 } \\
\text { 造 船 所 }\end{array}$}} & 係 \\
\hline & & & & & & & 船 \\
\hline 1 & $\mid \begin{array}{l}\text { アラスカ } \\
\text { (根岸) } \\
\text { (ニキスキ) }\end{array}$ & \begin{tabular}{|} 
・ 三菱商事 \\
・フィリップス \\
ペトロリアム \\
$(70 \%)$ \\
・マラソン・オイ \\
ル $(30 \%)$
\end{tabular} & 96 & $\begin{array}{c}\text { '69.11 } \\
\sim 15 \text { 年 } \\
(5 \text { 年延長) }\end{array}$ & $\begin{array}{l}71,500 \mathrm{~m}^{3} \times 2 \\
\text { ガストランスポ } \\
\text { ート・メンブレン }\end{array}$ & $\begin{array}{l}\text { コクムス造船所 } \\
\text { (スウェーデン) }\end{array}$ & $\begin{array}{r}\text { ・ポーラー } \\
\mathrm{LNG} \\
\text { シッピング } \\
\text { ・アークティッ } \\
\text { クLNG } \\
\text { トランスポー } \\
\text { テーション }\end{array}$ \\
\hline 2 & $\mid \begin{array}{c}\text { ブルネイ } \\
\text { (根岸, 袖ケ } \\
\text { 浦, 泉北第 1) } \\
\begin{array}{c}\uparrow \\
\text { (ルムット) }\end{array}\end{array}$ & $\begin{array}{l}\text { ・三菱商事 } \\
\text { ・シェル } \\
\text { ・ Brunei LNG } \\
\text { ・ブルネイ政府 }\end{array}$ & 514 & $\begin{array}{l}\text { '72. } 12 \\
\sim 20 \text { 年 }\end{array}$ & \begin{tabular}{|}
$75,000 \mathrm{~m}^{3} \times 5$ \\
テクニガス・x \\
ンブレン \\
$76,900 \mathrm{~m}^{3} \times 2$ \\
ガストランスポー \\
ト・メンブレン
\end{tabular} & $\begin{array}{l}\text { アトランティック, } \\
\text { ラシオタ C.N.I.M }\end{array}$ & $\begin{array}{l}\text { シェル・タン } \\
\text { カーズ }\end{array}$ \\
\hline 3 & $\mid \begin{array}{c}\text { アブダビ } \\
\text { (袖ケ浦) } \\
\ddagger \\
\text { (ダス島) }\end{array}$ & $\begin{array}{l}\text { - ADNOC (ア } \\
\text { ブダビ国営石 } \\
\text { 油会社) } \\
\text { ・三井物産 } \\
\text { ・三井液化ガス } \\
\text { - B P } \\
\text { - C F P }\end{array}$ & $\left(\begin{array}{r}205 \\
\mathrm{~L} \mathrm{P} \mathrm{G} \\
80\end{array}\right)$ & $\begin{array}{l}\prime 77.5 \\
\sim 20 \text { 年 }\end{array}$ & $\begin{array}{l}125,000 \mathrm{~m}^{3} \times 3 \\
\text { モス球型 } \\
87,600 \mathrm{~m}^{3} \times 1 \\
\text { モス球型 }\end{array}$ & 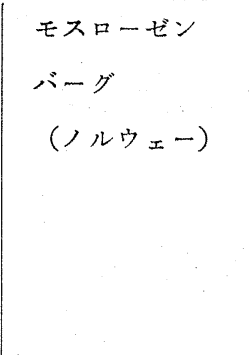 & $\mid \begin{array}{l}\text { ・゙タスラーセ } \\
\text { ソ } \\
\text { ・メタンキャリ } \\
\text { アズ }\end{array}$ \\
\hline 4 & $\mid \begin{array}{c}\text { インドネシア } \\
\text { （泉北第 } 2, \\
\text { 知多, 戸畑, } \\
\text { 恇路） } \\
\text { (ボンタン, } \\
\text { ロスマウェ) }\end{array}$ & \begin{tabular}{|l} 
・ブルタミナ \\
・日本インドネ \\
シア \\
LNG(JILCO) \\
・ービル・グ \\
ループ \\
ハフィントン・ \\
グループ
\end{tabular} & $\left.\begin{array}{r} \\
750 \\
\text { バダック } \\
300 \\
\text { ア } \\
450\end{array}\right)$ & $\begin{array}{l}\prime 77.8 \\
\sim 23 \text { 年 }\end{array}$ & $\begin{array}{l}125,000 \mathrm{~m}^{3} \times 7 \\
\text { モス球型 }\end{array}$ & $\begin{array}{l}\text { ジェネラル・ダ } \\
\text { イナミックス } \\
\text { (米 国) }\end{array}$ & $\begin{array}{l}\text { ・゚トリオッ } \\
\text { ト・シッピン } \\
\text { ・ LNGトラン } \\
\text { スポート } \\
\text { リクイッド・ } \\
\text { ガス・トラン } \\
\text { スポート }\end{array}$ \\
\hline 5 & $\mid \begin{array}{l}\text { サラワク } \\
\text { （袖ケ浦，扇 } \\
\text { 島） }\end{array}$ & $\begin{array}{c}\text { ・゚トロナス } \\
\text { (アレーシア国 } \\
\text { 営石油会社) } \\
\text { ・菱商事 } \\
\text { ・シェル }\end{array}$ & 600 & $\begin{array}{l}\text { '83.2 } \\
\sim 20 \text { 年 }\end{array}$ & $\begin{array}{l}130,000 \mathrm{~m}^{3} \times 5 \\
\text { ガストランス } \\
\text { ポート・メン } \\
\text { ブレン方式 }\end{array}$ & $\begin{array}{l}\text { ダンケルク(仏) } \\
\text { メデタランス(仏) }\end{array}$ & $\begin{array}{l}\text { MISC(マレー } \\
\text { シア・インター } \\
\text { ナショナル・シ } \\
\text { ッピング社) }\end{array}$ \\
\hline
\end{tabular}




\begin{tabular}{|c|c|c|c|c|c|c|}
\hline 供給ガス・油田 & $\begin{array}{l}\text { 液化積出 } \\
\text { 基 地 }\end{array}$ & $\begin{array}{c}\text { 液化プロセス } \\
(\text { (コントラクター） }\end{array}$ & 生 産 者 & 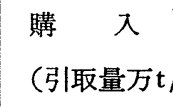 & & $\begin{array}{l}\text { 液 化 } \\
\text { プラントコスト } \\
\text { 輸送距離ほか }\end{array}$ \\
\hline $\begin{array}{l}\text { ノースクックイ } \\
\text { ソレット・ガス } \\
\text { 田 } \\
\text { ケナイ・ガス田 }\end{array}$ & Nikiski & $\begin{array}{l}\text { 改良カスケード法 } \\
\text { 86. } 3 \mathrm{MMcfd} \times 2 \\
\begin{array}{r}(フ ィ リ ッ フ ゚ ス, \\
\text { ベクテル }\end{array}\end{array}$ & $\begin{array}{r}\text { ・フィリップス } \\
\text { ・マラソン・ } \\
\text { オイル } 30 \%\end{array}$ & $\begin{array}{l}\text { - 東京電力 } \\
\text { - 東京瓦斯 }\end{array}$ & $\begin{array}{l}72 \\
24\end{array}$ & $\begin{array}{l}\text { CIF 契約 } \\
(1 \text { 億ドル) } \\
=キ ス キ ~ \\
(6,000 \mathrm{~km})\end{array}$ \\
\hline $\begin{array}{l}\text { サウスウェスト } \\
\text { アンパガス田 } \\
\text { セリアの油溶性 } \\
\text { ガス }\end{array}$ & Lumut & $\begin{array}{l}\text { Air Products } \\
\text { プロパン予冷 } \\
\text { MCR法 } \\
\text { 150MMcfd×5 } \\
\text { (日㫮, プロコン) }\end{array}$ & $\begin{array}{l}\text { Brunei LNG } \\
\text { Limited } \\
\text { ・ブルネイ政府 } \\
\text { ・三菱商事 } \\
\text { ・シェル各 } 1 / 3\end{array}$ & $\begin{array}{l}\text { • 東京電力 } \\
\text { - 東京瓦斯 } \\
\text { - 大阪瓦斯 } \\
\text { (第 } 1 \text { 次, 第 } \\
\text { 篍合計 }\end{array}$ & $\begin{array}{r}345 \\
106 \\
63 \\
2 \text { 次) }\end{array}$ & $\begin{array}{l}\text { CIF契約 } \\
(2.5 \text { 億ドル) } \\
\\
\text { ルムット } \\
(4,400 \mathrm{~km})\end{array}$ \\
\hline $\begin{array}{l}\text { ザクム, ウムシ } \\
\text { ヤイフ油田中心 } \\
\text { 随伴ガス }\end{array}$ & ダス島 & $\begin{array}{l}\text { Air Products } \\
\text { プロパン予冷 } \\
\text { MC R法 } \\
250 \mathrm{MMcfd} \times 2 \\
\text { (千代田化工, ヘ } \\
\text { クテル) }\end{array}$ & $\begin{array}{l}\text { ADGLC } \\
\text { (構成は主要 } \\
\text { 関係者と同じ) }\end{array}$ & 東京電力 & 206 & $\begin{array}{l}\text { CIF 契約 } \\
\text { ( } 5 \text { 億ドル) }\end{array}$ \\
\hline $\begin{array}{c}\text { バダック・ガス田 } \\
\text { (東カリマンタン) } \\
\text { アルン・ガス田 } \\
\text { (北スマトラ) }\end{array}$ & $\begin{array}{c}\text { ・゙ダック } . . \\
\cdots \text { ボンタン } \\
\text { ・アルン...... } \\
\text { ロスマウェ }\end{array}$ & $\begin{array}{l}\text { Air Products } \\
\text { プロパン予冷 } \\
\text { MCR法 } \\
\text { バダック } \\
225 \mathrm{MMcfd} \times 2 \\
\text { (ベクテル) } \\
\text { アルン } \\
200 \mathrm{MMcfd} \times 3 \\
(\text { ベクテル) }\end{array}$ & \begin{tabular}{|l|} 
・ P Tバダック \\
液化会社 \\
(300万t/年) \\
プルタミナ \\
$\mathrm{JILCO}$ \\
$\mathrm{HAFFCO}$ \\
・ P Tアルン液化 \\
会社 \\
(450万t/年) \\
プルタミナ \\
$\mathrm{JILCO}$ \\
モービル・グル \\
ープ
\end{tabular} & $\begin{array}{l}\text { - 関西電力 } \\
\text { - 中部電力 } \\
\text { - 九州電力 } \\
\text { - 大阪瓦斯 } \\
\text { - 新 日 鉄 }\end{array}$ & $\begin{array}{r}240 \\
170 \\
150 \\
130 \\
60\end{array}$ & $\begin{array}{l}\text { CIF契約 } \\
\text { (バダック } \\
7 \text { 億ドル) } \\
(ア ル ン ~ \\
9 \text { 億ドル) } \\
\text { ボンタン } \\
(4,600 \mathrm{~km}) \\
\text { ロスマウェ } \\
(6,100 \mathrm{~km})\end{array}$ \\
\hline $\begin{array}{l}\text { セントラル・ル } \\
\text { コニア・ガス田 } \\
\text { (ビンツル沖) }\end{array}$ & $\begin{array}{l}\text { ビンツル } \\
\text { (Bintulu) }\end{array}$ & $\begin{array}{l}\text { Air Products } \\
\text { プロパン予冷 } \\
\text { MCR法 } \\
280 \mathrm{MMcfd} \times 3 \\
\text { (日揮, ケロッグ) }\end{array}$ & $\begin{array}{l}\text { マレーシア LNG } \\
\text { （構成は主要関係 } \\
\text { 者と同じ） }\end{array}$ & $\begin{array}{l}\text { 東京電力 } \\
\text { 東京瓦斯 }\end{array}$ & $\begin{array}{l}400 \\
200\end{array}$ & $\begin{array}{l}\text { CI F 契約済 } \\
(17 \text { 億ドル }) \\
\text { ビンツル } \\
(4,600 \mathrm{~km})\end{array}$ \\
\hline
\end{tabular}


(2) 計画中のプロジェクト

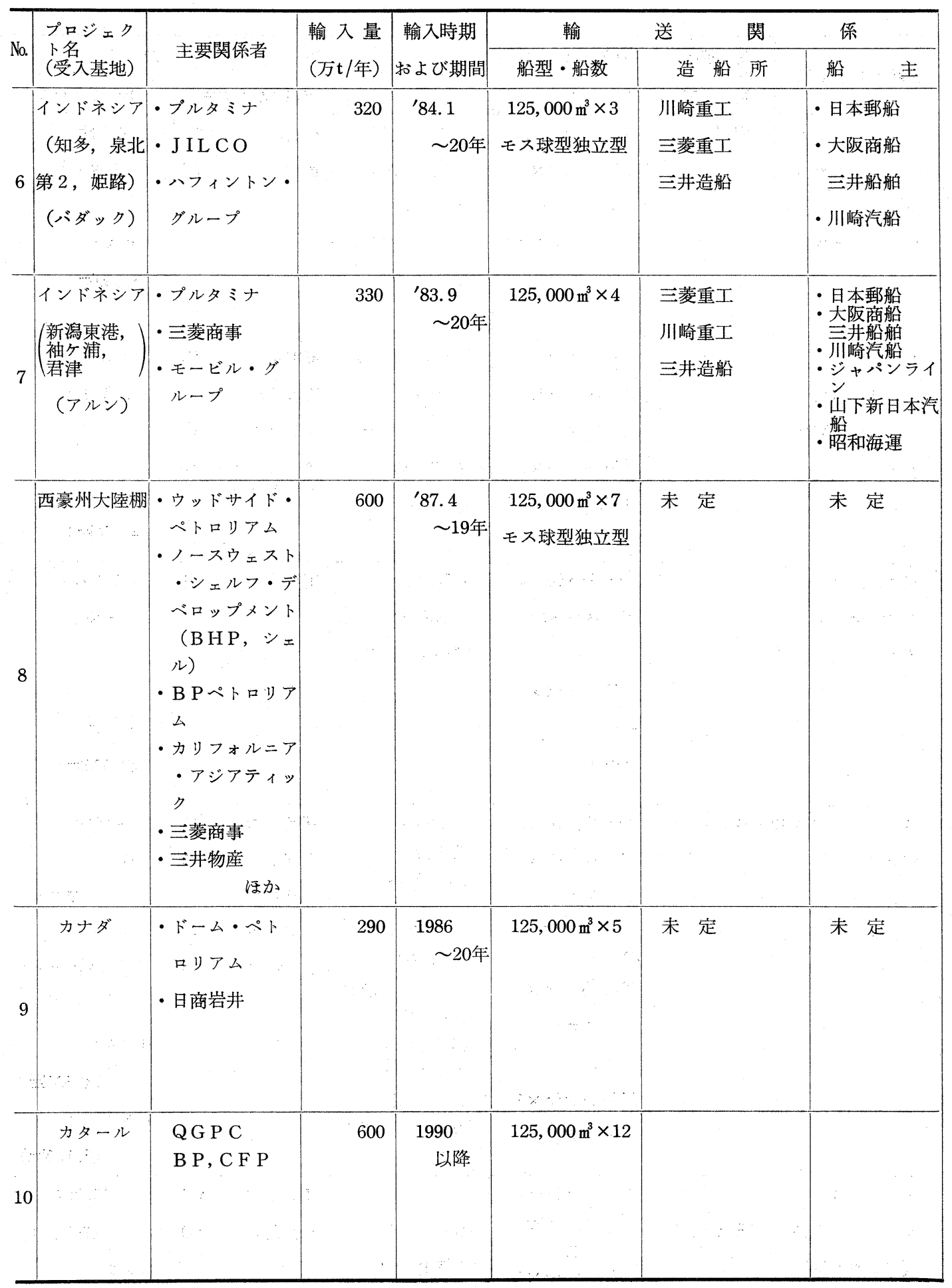




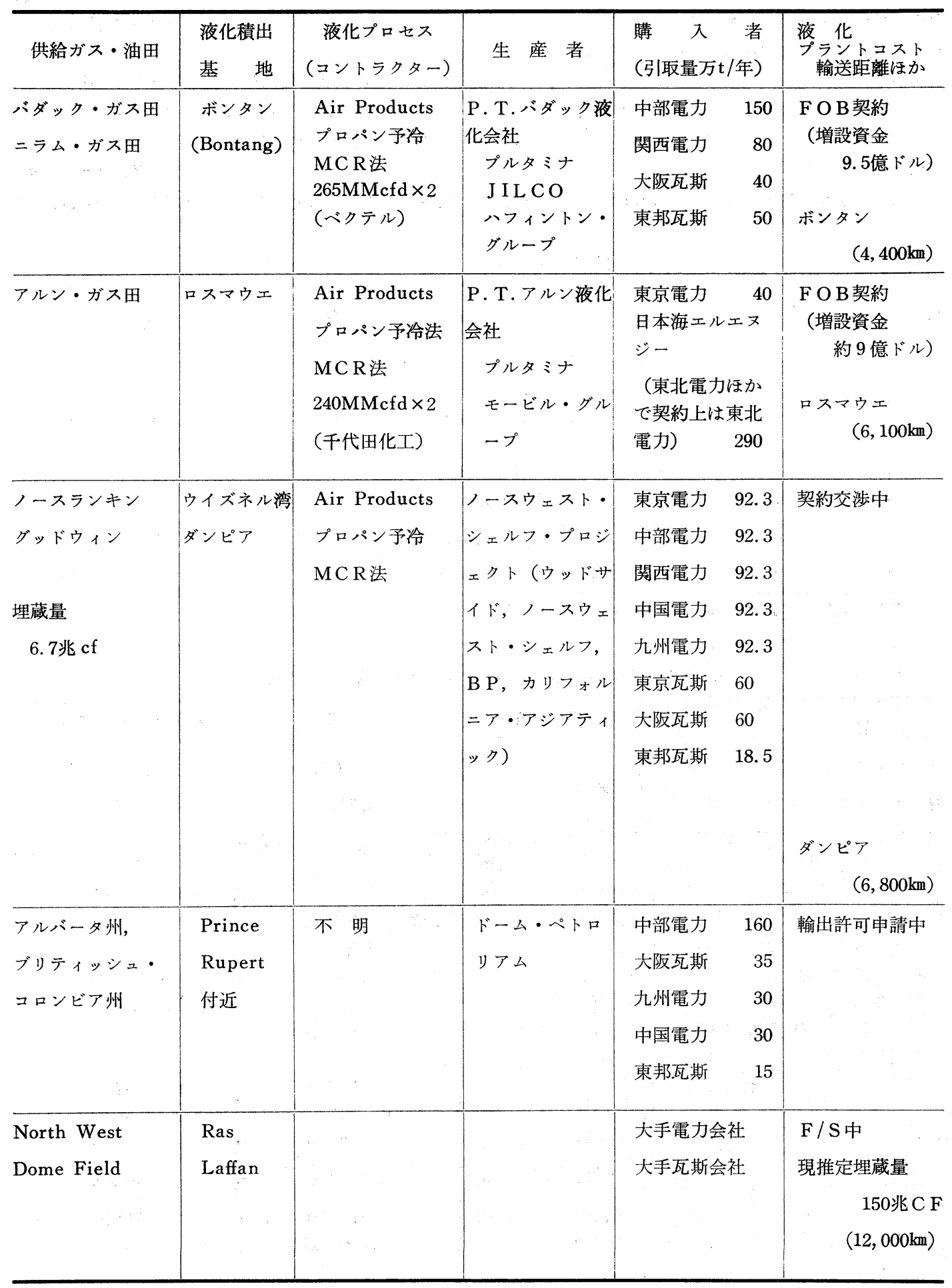


とくに, 新潟県長岡地区に颃いては, 深度 $5,000 \mathrm{~m}$ 程度の深部グリーンタフ層で日量 $200,000 \mathrm{~m}^{3}$ 以上の天 然ガスを確認した坑井もあり，前途に明るい希望を与 えている。

海域は国の基礎試錐 2 坑を含む 8 坑が試掘された。 油・ガス徵を認めた有望な試掘井が 2 坑あり, 今後の 探鉱が期待されている。

また，水溶性天然ガスは昨年とほぼ同様に，4.5億 $\mathrm{m}^{3}$ の生産量が確保され，57年度には，千葉県下で新規 に16坑が掘削され，それぞれ天然ガスの発見に成功し ている。

\subsection{N G（液化天然ガス）の輸入と利用}

L NGが本格的に利用されはじめたのは，44年東京

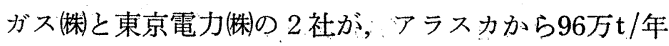
の L N Gを受け入れてからである。以降, 大阪瓦斯(侏), 関西電力(侏), 中部電力(侏), 九州電力(侏)な゙の各社がつ

表 5-7 世界の L N G プロジェクト（稼行中）

\begin{tabular}{|c|c|c|c|c|c|c|}
\hline 輸 & 出 国 & 輸 入国 & 社 & 地 & $\begin{array}{l}\text { 取 引 } \\
\text { 開始年 }\end{array}$ & $\begin{array}{l}\text { 年 間 } \\
\text { 取引量 }\end{array}$ \\
\hline \multicolumn{2}{|c|}{ アルジェリア } & フランス & SONATRACH, Gaz de France & ルアーブル & 1965 & 38 万 $\mathrm{t}$ \\
\hline リ & $\boldsymbol{\gamma}$ & スペイン & Sirte Oil Co., ENAGAS & バルセロナ & 1969 & $83 \prime \prime$ \\
\hline \multirow{2}{*}{\multicolumn{2}{|c|}{ アルジェリア }} & フランス & \multirow{2}{*}{$\begin{array}{l}\text { SONATRACH, Gaz de France } \\
\text { SONATRACH, Distrigaz }\end{array}$} & フォスルメール & 1972 & $260 \prime \prime$ \\
\hline & & アメリカ & & エ ヘ $レ ッ ト$ & $\prime \prime$ & $90 \prime \prime$ \\
\hline & " & スペイン & SONATRACH, ENAGAS & バルセロナ & 1974 & $340 \prime \prime$ \\
\hline & $\prime \prime$ & ベルギー & SONATRACH, Distrigaz & ゼーブル:ッゲ & 1982 & $375 \prime \prime$ \\
\hline & $" \prime$ & アメリカ & $\begin{array}{l}\text { SONATRACH, トランクライン } \\
\text { パンハンドル・イースタンほか }\end{array}$ & レイクチャールズ & 1982 & $340 \prime \prime$ \\
\hline & " & フランス & SONATRACH, Gaz de France & ブルター = = & $\prime \prime$ & $390 \prime \prime$ \\
\hline
\end{tabular}

資料：天然ガス鉱業会調べ（1983.4 現在）

表 5-8 長期エネルギー需給見通し (57.4.21)

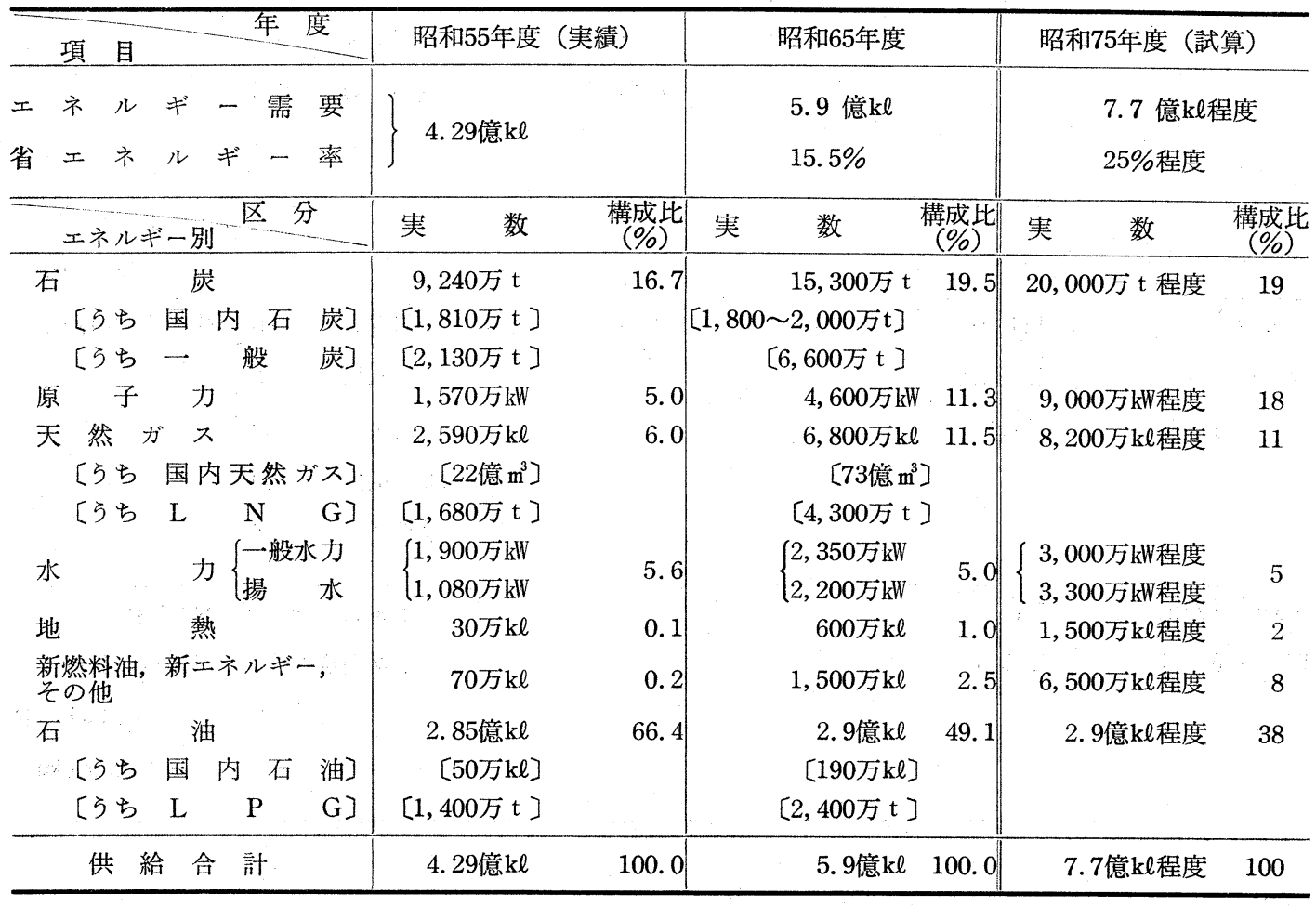


ぎつぎと L N G導入を開始したことから，L N G 利用 は電力用, 都市ガス用を中心として急速な拡大を遂げ ることになった。
L NGの輸入は比較的順調に進み，アラスカに続い て，ブルネイ，アブダビ，インドネシアの輸入が寒現 した㴗か，58年 2 月にはサラワクから第一船が袖ケ浦

表5-9世界の天然カス確認埋蔵量 (単位：億 $\mathrm{m}^{3}$ )

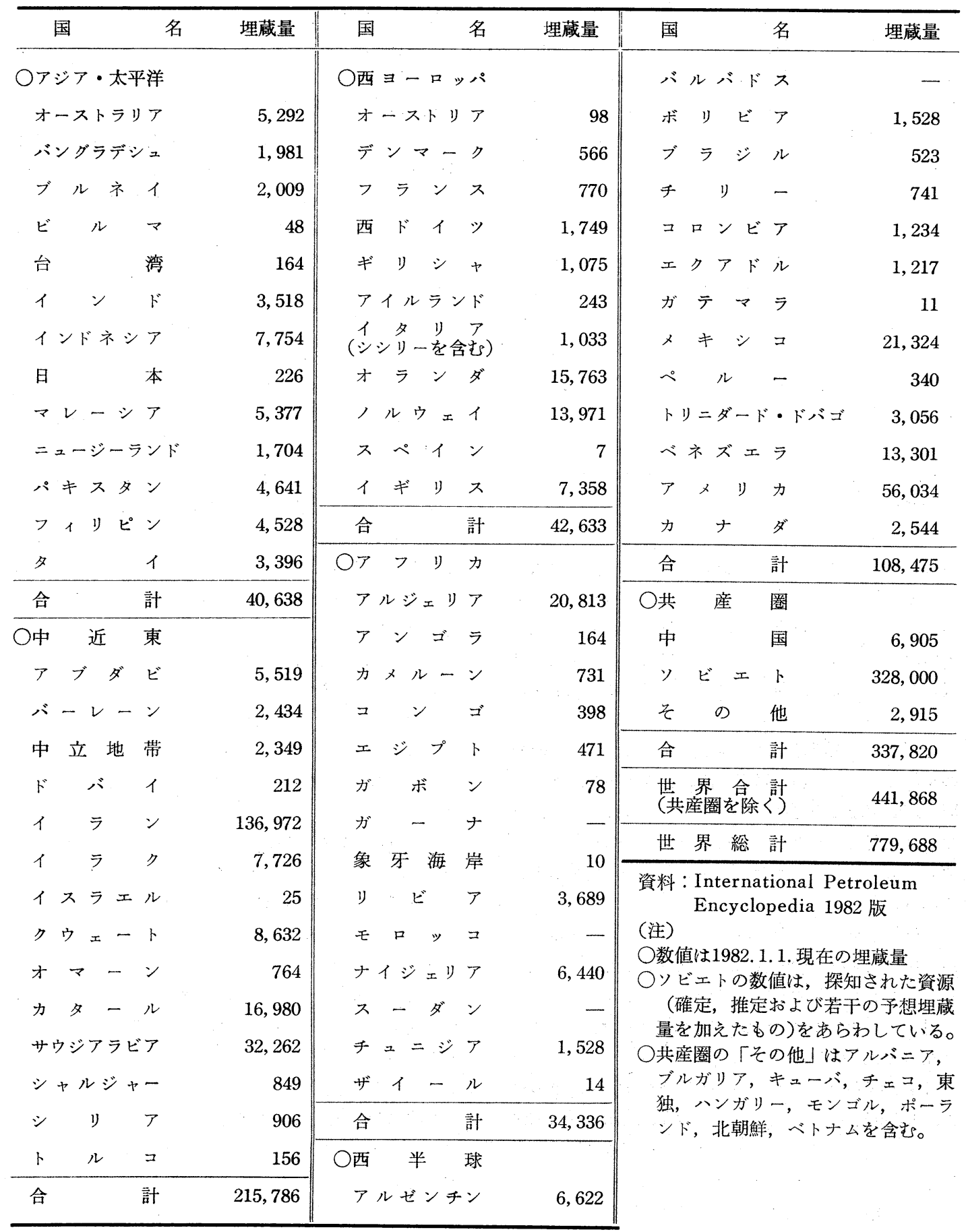


に入港している。さらにオーストラリア，カタールな ぞからの商談も進行中であり，すでに世界の L NG流 通量の半ば以上を日本が占めるに至っている（表5-4, 表 5-5 参照)。

現在操業中の L NGプロジェクトと計画中のものを おの拈の，表5-6および表5-7に示す。

将来の天然ガス需要見通しについて述べれば，政府 は目下「長期エネルギー需給見通し」の改訂を進めて おりり，57年 4 月に策定されたものによると，65年度に 括ける国内天然ガスの生産量は73億 $\mathrm{m}^{3}$, 輸入 L N Gは 4,300 万t と増加すると見込まれている（表5-8参照）。

\section{2. 世界の天然ガス埋蔵量}

世界の天然ガスの確認埋蔵量はインターナショナル ・ペトローリアム・エンサイクロペディア（1982版） によると 82 年には 78 兆 $\mathrm{m}^{3}$ とれ，そのうち共産圈が 33.8 兆 $\mathrm{m}^{3}(43 \%)$, 中近東 21.6 兆 $\mathrm{m}^{3}(28 \%)$, 西半球 10.8 兆 $\mathrm{m}^{3}(14 \%)$, 西寻一ッハ 4.3 兆 $\mathrm{m}^{3}(6 \%)$, ア ジア，太平洋は 4.1 兆 $\mathrm{m}^{3}(5 \%)$ である。

また，国別の埋蔵量は，ソ連は 32.8 兆 $\mathrm{m}^{3}$, イラン 13.7 兆 $\mathrm{m}^{3}$ ，第 3 位はアメリカの 5.6 兆 $\mathrm{m}^{3}$ となっている（表 $5-9$ 参照)。

\section{3. アメリカ}

NG P A（天然ガス政策法：1978年）による天然ガ ス価格の段階的な引き上げは，探鉱活動に一時活力を 与光, 天然ガスの新規発見量が1979年には 4,050 億 $\mathrm{m}^{3}$ 之増加したにもかかわらず，既開発地域の再開発や見 直しが多く，また，同年の生産量水準 5,640 億 $\mathrm{m}^{3}$ をか なり下まわっている。

アメリカの生産量は，世界第一位であり，これを維 持するためには相当な規模の探鉱を行う必要があるが 国土が広大なためと口ケーションによって，アラスカ 州や大陸棚などの探鉱が未だ十分には行われていない 地域があり，追加埋蔵量の数値にはかなりの幅が生じ ている。

1981年末をピークをする“ブーム”ともい方る程の 活発な堀削活動が行われたが，現在は停滞し，確認埋 蔵量の增加に寄与することが少なかった。

現在, アメリカの天然ガス確認埋蔵量は, 5.7 兆 $\mathrm{m}^{3}$ と見積られている。

日本と関係の深いアラスカ州の天然ガス確認埋蔵量 は，9,630億 $\mathrm{m}^{3}$ そのぼる。このらち約 2,270 億 $\mathrm{m}^{3}$ は南ア ラスカに賦存している。北部の開発が期待されるが, 実際にはパイプライン建設などの輸送手段や操業コス ト，稼行期間の気候的な制限などの難問を解決せねば
ならず，カナダのボーフォート海と北極諸島での成功 にもかかわらず，あまり楽観的な見通しはできない。 また，在来型の隇耗を補完するとみられている非在 来型の天然ガスは, 収益性の問題や開発技術上の問題 から着手が遅れているが，その賦存量には莫大なるの があり将来に期待がもてる。

非在来型のガスとしては，(1)デボニアン・シェール ガス，(2)タイト・サンド・ガス，(3)地圧ガス，(4)炭田 ガス，(5)バイオマス・ガス，などがあげられるが，こ のらち炭田ガス だけでも，2,000〜24, 000 億 $\mathrm{m}^{3}$ の埋蔵 量が見積られている。これらは炭田ガスを除いて開発 が遅れているが，2000年までの予想生産量として， DOE : 850 1, 980億 $\mathrm{m}^{3}$, A GA : 1, 130 3, 110億 $\mathrm{m}^{3}$ とする見通しがたてられている。

NG P A ，その目的を低価格による天然ガス浪費 の防止，生産者の開発意欲の克進を図ることに打いて いたが，複雑かつ細部に渉る規制であったため，現実 との喰い違いが甚だしくなってきたことやレーガン 政策が政府支出を抑党る方向で展開されているため に，非在来型や代替エネルギーの開発が停滞している が，1985年の時点で価格統制が解除されれば，探鉱活 動も盛んになり，開発技術の向上とも相俟って，天然 ガスの生産量が増大するるのと思われる。ただ，現在 でもその兆候がみられるが，各州間の利害対立などが 尖鋭化し，環境保護などの立場からの消費者団体の政 治的なプレッシャーによって, 規制解除が実際に行わ れるかどらかは予断を許さない。

\section{4. インドネシア}

インドネシアの 確認埋蔵量は, 1969 年に185億 $\mathrm{m}^{3}$ 程 度であったが，アルン，バダックの両ガス田が発見さ れたことにより80年には 6,790 億 $\mathrm{m}^{3}$ と飛躍的に増大し た。

82 年現在, 7,700 億 $\mathrm{m}^{3}$ と確認埋蔵量がさらに增加し, 輸出可能余剩として 2,000 億 $\mathrm{m}^{3}$ 有している。今後ナ ッナ計画 (1990年以降800万tの L NG生産の予定)な ぞが実施された場合には，さらに増大するるのと思わ れる。

将来, 米国向けとしてL N G55億 $\mathrm{m}^{3}$ 輸出する合意 が成立している。現在，日本としては最大の L N G 導 入先である。

\section{5. 西欧諸国}

西欧に和ける天然ガス産出国としては，オランダ， イギリスの注かに数ヶ国があげられるが，生産量その 他の関係からオランダとイギリスとした。

オランダの確認埋蔵量は 1 兆 5,780 億 $\mathrm{m}^{3}$ とされてい 
るが，ほかに推定埋蔵量として 6,720 億 $\mathrm{m}^{3} か ゙$ 見積られ ている。オランダはフローニンゲンガス田の発見以 来, アメリカ, ソ連に次ぐ第 3 位のガス生産国であっ たが，政府の開発政策が変更されてフローニンゲンの ガスを戦略埋蔵量とすることが決定されたため, 生産 量を漸減し, 95 年には輸出量を 130 億 $\mathrm{m}^{3}, 2,000$ 年には 既輸出契約分を完了し，生産総量全部を国内利用とす ることを計画している。

イギリスの天然ガスは, 大半が北海南部海域のガス 田から産出されており，これらの生産量は80年後半に は減少するだろうといわれている。確認埋蔵量は, 6,640 億 $\mathrm{m}^{3}$, 推定埋蔵量は7, 410億 $\mathrm{m}^{3}$ と見达まれている が，イギリスエネルギー省はさらに650〜6, 600億 $\mathrm{m}^{3} の$ 追加埋蔵量を期待している。

イギリスでは，国内資源の開発をおくらせる政策が とられ輸入が奖励されている。また，税制措置が財政 政策の観点から行われているために，追加石油税が課 せられ，探鉱・開発促進にとって障害となっている。

\section{6. カナダ}

NE P（国家エネルギー計画：1980年）によって, 探鉱・開発の重点がフロンティア地域へと移行しアア メリカ同様に探鉱活動の活発化がみられたが，連邦政 府と州政府の間にはエネルギー政策をめぐって対立が あり, また, 輸出減退や国内需要の伸び悩みで前途は 多難である。NEB（国家エネルギー委員会）の推計 によれば, 1980年末の確認埋蔵量は 2.5 兆 $\mathrm{m}^{3}$ であるが, 究極可採埋蔵量は最大 54.2 兆 $\mathrm{m}^{3}$ と推計されている。生 産能力に関しては, 2000年の時点で 298 億 $\mathrm{m}^{3}$ とされて いるので, フロンティア地域の開発促進が今後の課題 と考えられる。NE Pは1982年に修正されたが，原油 の值下がりなどによって, 現在さらにシーリングプラ イスの見直しが行われている。

\section{7. ノルウェイ}

1981年の生産量は, 石油 2,360 万 $\mathrm{t}$, 天然ガス 260 億 $\mathrm{m}^{3}$ で, ガスは国内での需要が皆無のため, その全量が 輸出に向けられている。

現在稼行中の油田はエコフィスク油田群, ムルチン ソン,スタットフィヨルド油田などであり,フリッグガ ス田を含めて11の油・ガス田がある。この注か，5つ の油・ガス田が開発を認可されて拈り，これら油・ガ ス田を合わせると，1981 年末天然ガ ス 確認埋蔵量は 8,290 億 $\mathrm{m}^{3} て ゙ ，$ 可採埋蔵量は 4,740 億 $\mathrm{m}^{3}$ と見積られてい る。累計生産量は 890 億 $\mathrm{m}^{3}$ の生産量である。輸送シス テムとしては, (1)エコフィスク・パイプライン, (2) フ リッグ・パイプライン，(3)スタット・パイプラインの
3つがあり，(1)，(2)はすでに操業中であるが，(3)は86 年に操業開始予定で, 北海の天然ガスをヨーロッパ大 陸に輸送する 3 本のパイプラインによる計画である。 北海の開発は鉱床の規模や厳しい自然条件のため に，開発ュストがかさむ可能性や生産のおくれをもた らす要素がある。

また，北緯 $62^{\circ}$ 以北での発見は，すぐに開発にはも すびつかず，大規模な生産を行うためにはL N G 輸送 方式か, 長距離パイプライン方式のいずれかのプロジ ェクトの実現がまたれる。

\section{8. オーストラリア}

オーストラリアではパィプライン網の整備に伴い, 1970年を契機として天然ガスの生産が飛躍的に向上 し, 80 年には日産 9 億 5,000 万 $\mathrm{m}^{3}$ と 6 倍以上の伸びを 示した。西オーストラリアおよびクイーンズランド州 は停滞しているが, 南オーストラリアとビクトリア州 では生産が活発に行われて拈り，この 2 州だけで同国 の生産量の 8 割強をまかなっている。

ビクトリア州ではギップスランド堆積盆, クイーン ズランド州ではボーェン・スラット堆積盆, 南オース トラリア州ではクーパー堆積盆が開発の中心であり, 今後のパイプライン網の整備に伴って今後増産が行わ れるものと思われる。

\section{9. ニュージーランド}

最大のガス田はオフショアのマウイガス田であり, 天然ガス約 1,500 億 $\mathrm{m}^{3}$, ユンデンセート約 2,500 万 $\mathrm{k} \ell の$ 究極埋蔵量が見込まれて和り，1979年6月から生産が 開始されている。この他には陸上にカプニガス田など がある。天然ガスの生産量は77年 23.4 億 $\mathrm{m}^{3}, 80$ 年には 13.4億 $\mathrm{m}^{3}$ と減少している。

今後の予測として, 同国の専門家筋によればマウイ 級ガス田が 1 つ，カプニ級ガス田が 5 つ程度発見され る可能性が高いとされている。

\section{0. ソ 連}

ソ連は, 1981年に始まる第11次 5 力年計画の中で, 天然ガスの大増産方針を打ち出して扣り, 同計画の最 終年度である 85 年の生産目標は $6,000 \sim 6,400$ 億 $\mathrm{m}^{3}$ に設 定されている。これは 80 年実績の $50 \%$ 増に相当する。 天然ガスの総生産量は1975年の 2,830 億 $\mathrm{m}^{3}$ から82年に は 5,010 億 $\mathrm{m}^{3}$ と増大している。

とくに，黒海预よびアスピ海地域から西シベリアの 開発に重点が移されたため, チュメ二州, トムスク州 に㧅いて急速に開発が進められている。その他，トル クメン, ウズベク共和国でも生産が行われている。 ウレンゴイの埋蔵量は, 1,400 億 $\mathrm{m}^{3}$ といわれており, 
世界最大規模のガス田である。ソ連全体としての天然 ガス埋蔵量は, 確認, 推定および予想の総計で約 35 兆 $\mathrm{m}^{3}$ と見積られている。

ソ連のパイプライン建設は，幹線総計で1960年には 2,100kmであったが，81年には $136,000 \mathrm{~km}$ も達する驚 異的な進渉をみせている。

またアアメリカとの間で摩擦のあった西欧向パイプ ラインは，契約が皃ば完了し西独には1984年秋頃から 供給される見通しである。

サハリン大陸棚の開発は，アメリカの経済制裁によ って一時開発に支障を来たしたが，今後わが国の協力 によってオドプト構造の探鉱が続けられることになっ ている。

\section{1. 中近東}

イランの天然ガス確認埋蔵量は, ソ連についで世界 第 2 位で13.7 兆 $\mathrm{m}^{3}$ のち約 $40 \%$ が油田ガスである。ガ ス田ガスはカンガン地域からペルシャ湾の中央部に向 って賦存している。イランはこの莫大な天然ガスを輸 出する計画をたてていたが, 戦争のため中断され, 部 分的に完成したパイプライン他は国内供給用として利 用される見通しである。

サウジアラビアの 天然ガス 確認埋蔵量は, 3.2 兆 $\mathrm{m}^{3}$ でOPEC諸国ではイラン，アルジェリアについで第 3 位で，そのほとんどが油田ガスであり，1975年に集 ガス, 処理プラント建設計画に着手したが, 油田ガス は国内で消費し，ガス田ガスは温存する政策からみて 当分の間対外輸出の見込は薄いと思われる。

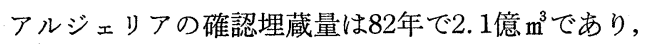
さらに未確認埋蔵量は 5 兆 $\mathrm{m}^{3}$ 以上と推定されている。 アルジェリアは世界で初の輸出L N G の大型開発を行 った国であるが，確認埋蔵量の 1.7 億 $\mathrm{m}^{3}$ は輸出既契約 分とみられていたが, 資本費, 運転費が高いことから， ヨーロッパやアメリカとの L N G契約が破棄, 中断し ている。今後は, 地中海横断パイプラインが技術的に 成功したことにより，パイプラインによる輸送に大き く移行することになるとみられている。 ガス田としては，ローデヌースガス田が開発の中心 となり，探鉱費は 5 億ドルが予定されている。

12. メキシコ

メキシコ北部のサビナス 堆積盆は遊離型鉱床が多 く, 中, 南部の油田地帯ではほとんどが油田ガスであ る。1972年以降カンペチェ油田など南部の開発が盛ん になり, 天然ガスの確認埋蔵量が増加し, 最近のペメ ックスの調査によれば, ガス田ガスで 2.3 兆 $\mathrm{m}^{3}$, 油田

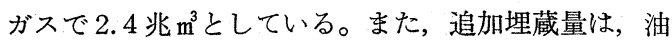

・ガス田ガスを併せて11.3兆 $\mathrm{m}^{3} か ゙$ 見積られている。油 田ガスは注とんどが国内利用に向けられて拈り，今後 はガス田の開発が問題となってくるようである。

\section{3. 今後の展望}

天然ガスは，今や石油に替わる主要エネルギー供給 源として, 産がス, 消費国を問わずその開発・利用が 急伸しているが，現今の流動的で不透明な世界のエネ ルギー情勢を考学ると, 国産天然ガスはエネルギーセ キュリティの上からもきわめて重要な資源として位置 づけれ，長期的な視点に立って探鉱・開発を進めて 行く必要がある。

さいわい, わが国の石油・天然ガスの確認埋蔵量は

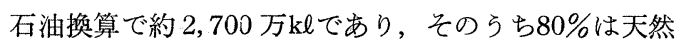
ガスの形で埋蔵されているといわれ，しかるイオウな どの不純物を含まない無公害の原燃料としてそのまま 使用できる。

55 年度からは, 新規に通商産業省の石油・天然ガス 開発 5 力年計画が発足して和り, 従前とは異なって, 海域, 陸域での基礎試錐をはじめ, 財政措置の強化・ 拡充，技術開発の促進，開発体制の強化を内容とする 画期的な方針が織りこまれている。

ここでは, 5 年間に約 2,000 億円の探鉱投資を行い, 石油・天然ガス発見量 9,600 万 $\mathrm{k} \ell$ (原油換算), 60 年度 の生産量800万klの達成が目標として揭げられている。 5 力年計画もすでに 3 年経過したが, 秋田県, 新潟県 の陸域, 新潟県沖の海域では前に述べたと和り有望な 油・ガス田を発見している。

とくに海域での探鉣・開発事業は, 直接国内の安定 的な供給源の確保につながるばかりでなく, 国内関連 産業の振興, 雇用の拡大を通じて地域経済の寄与, 海 外進出の基盤，ひいては海洋開発全般に対する技術基 盤の確立など，はかり知れない大さな寄与が期待され る。

天然ガス資源は，世界的にる原油に比べてはるかに 豊富に賦存して特り, 輸入されるLNGにしても今後 は単に燃料として利用するのみでなく, コストの低減 化と新しい利用技術の開発による用途の拡大が必要と ならう。天然ガスを燃料ィタノールに变換して輸送, また，液体燃料として内燃機関その他で利用する構想 の実現も確実視されている。 


\section{2 都市ガス需給と原料の動向}

\section{1. 概 要}

都市ガス事業は戦後一貫して民生用を中心として, その需要家数, ガス販売量の拡大に努めてきた。また 2 度にわたるオイルショックに対してもすでに進めつ つあった石油系原料への依存体質をL N Gを中心とす る非石油系原料依存への転換をさらに進めることによ って乗り切り, 国の総合エネルギー政策の推進に多大 の貢献をしてきた。

表 5-10 年別一般ガス事業者数, 需要家数, ガス販売量

\begin{tabular}{rrrr}
\hline 項目 & $\begin{array}{c}\text { 航ガス } \\
\text { 事業者数 }\end{array}$ & $\begin{array}{c}\text { 需要家数 } \\
\text { (千個) }\end{array}$ & \multicolumn{1}{c}{$\begin{array}{c}\text { ガス販売量 } \\
\text { (百万kcal) }\end{array}$} \\
\hline 20 & 75 & 932 & 924,599 \\
21 & 75 & 1,049 & 804,316 \\
22 & 75 & 1,101 & $1,287,981$ \\
23 & 74 & 1,168 & $1,981,842$ \\
24 & 76 & 1,318 & $2,648,909$ \\
25 & 77 & 1,488 & $3,467,103$ \\
26 & 77 & 1,733 & $4,500,690$ \\
27 & 78 & 1,828 & $5,479,084$ \\
28 & 81 & 2,036 & $6,383,759$ \\
29 & 87 & 2,212 & $7,383,648$ \\
30 & 90 & 2,435 & $8,197,009$ \\
31 & 100 & 2,734 & $9,387,724$ \\
32 & 108 & 3,095 & $10,907,050$ \\
33 & 120 & 3,486 & $11,826,594$ \\
34 & 131 & 3,903 & $13,069,011$ \\
35 & 149 & 4,359 & $14,862,581$ \\
36 & 156 & 4,810 & $16,682,303$ \\
37 & 182 & 5,296 & $18,569,754$ \\
38 & 192 & 5,779 & $20,804,762$ \\
39 & 203 & 6,310 & $22,558,625$ \\
40 & 212 & 6,856 & $25,678,910$
\end{tabular}

7,427

8,033

8,719

9,434

10,189

10,951

11,711

12,503

13,266

13,800

14,377

14,909

15,494

16,103

16,646 17,046

$28,210,127$

$31,565,811$

$35,498,669$

$38,752,995$

$44,465,444$

$48,468,991$

$52,579,706$

$58,392,203$

$65,437,815$

$69,859,590$

$75,748,122$

$77,794,060$

$80,631,822$

$82,475,184$

$91,412,501$ $97,029,991$

(注) 需要家数はメーター取付数である。

出典：ガス事業便覧（昭和57年版）

表 5-11 需要家数別一般ガス事業者数 （昭和57年 12 月末現在）

\begin{tabular}{|c|c|c|c|}
\hline 需要家数 & 私営 & 公営 & 計 \\
\hline 1,000個以下 & 5 & 一 & 5 \\
\hline $1,001 \sim 2,000$ & 15 & 11 & 26 \\
\hline $2,001 \sim 3,000$ & 23 & 13 & 36 \\
\hline $3,001 \sim 4,000$ & 18 & 9 & 27 \\
\hline $4,001 \sim 5,000$ & 11 & 6 & 17 \\
\hline $5,001 \sim 10,000$ & 28 & 18 & 46 \\
\hline $10,001 \sim 50,000$ & 53 & 14 & 67 \\
\hline $50,001 \sim 100,000$ & 8 & 1 & 9 \\
\hline $100,001 \sim 300,000$ & 9 & 1 & 10 \\
\hline $300,001 \sim 500,000$ & 1 & - & 1 \\
\hline 500,001個以上 & 4 & - & 4 \\
\hline 計 & 175 & 73 & 248 \\
\hline
\end{tabular}

(注) 需要家数はメーター取付数である。

出典：ガス事業便覧（昭和57年版）

表 5-12 主, 要地区のガ ス 普及状況

\begin{tabular}{|c|c|c|c|c|}
\hline 主要地区別 項目 & $\begin{array}{c}\text { 供給区域内世帯数 } \\
(\text { 户) }\end{array}$ & $\begin{array}{c}\text { 需要家 数 } \\
\text { (個) }\end{array}$ & $\begin{array}{c}\text { 56年末普及率 } \\
(\%)\end{array}$ & $\begin{array}{c}\text { 55年末䶊及率 } \\
(\%)\end{array}$ \\
\hline 東京瓦斯本社地区 & $6,469,140$ & $5,924,244$ & 91.6 & 92.9 \\
\hline 大阪瓦斯京阪神地区 & $4,643,700$ & $4,330,268$ & 93.3 & 93.3 \\
\hline 東邦瓦斯全地区 & $1,255,977$ & $1,089,976$ & 86.8 & 87.6 \\
\hline 西部瓦斯福岡地区 & 350,900 & 284,320 & 81.0 & 80.3 \\
\hline 北海道瓦斯札幌地区 & 388,092 & 228,233 & 58.8 & 60.7 \\
\hline 広島ガス広島地区 & 310,377 & 201,370 & 64.9 & 63.0 \\
\hline その他地 区 & $8,584,713$ & $4,987,308$ & 58.1 & 57.1 \\
\hline 全 国 合 計 & $22,002,899$ & $17,045,719$ & 77.5 & 77.5 \\
\hline
\end{tabular}

出典：ガス事業統計年報（昭和56年版） 

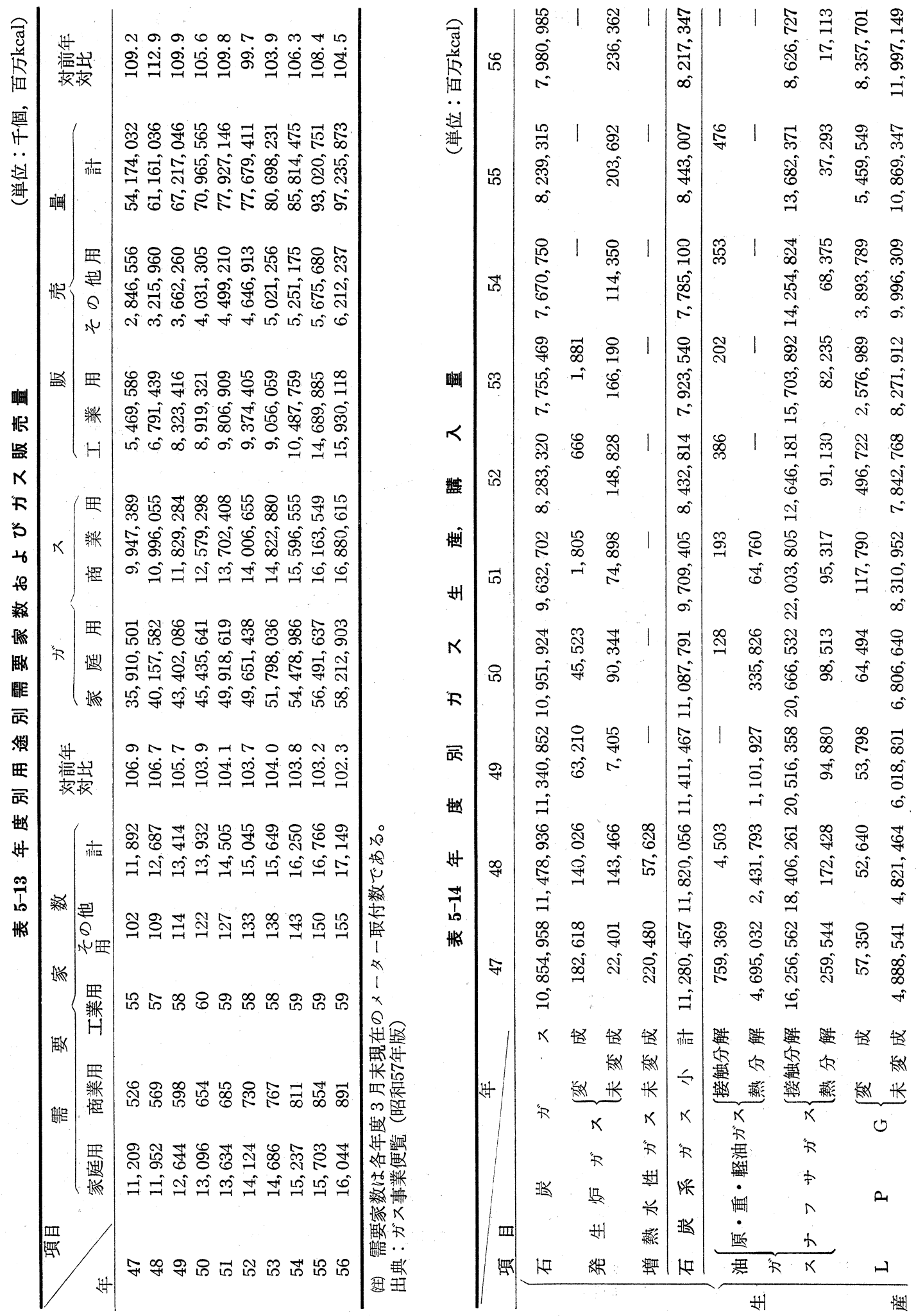


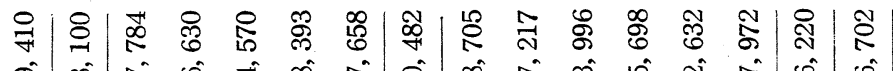

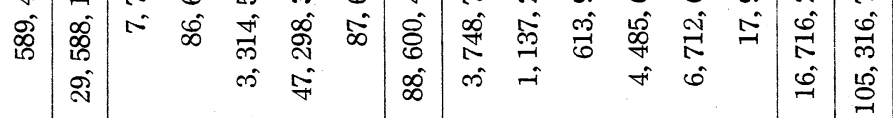

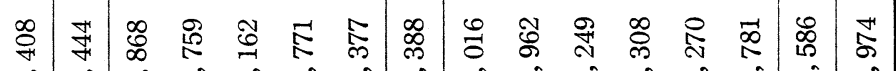

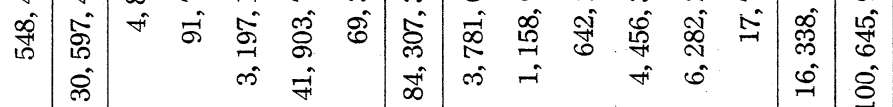

₹

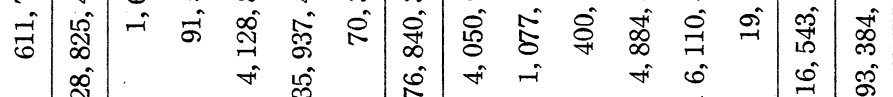

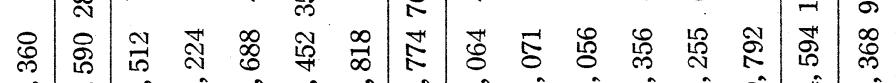
苦商

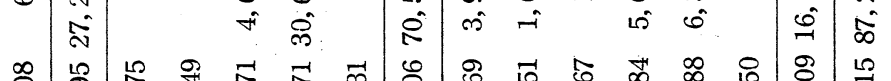
品

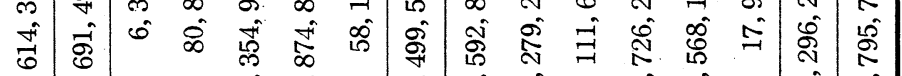
की एक \&

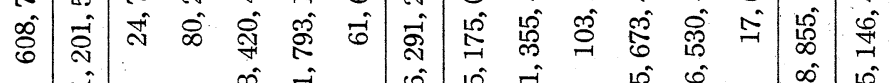

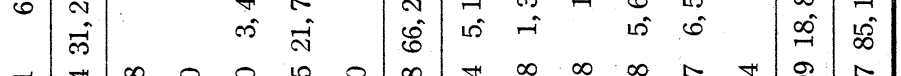

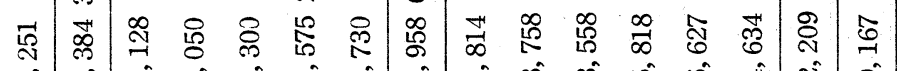
กิ่

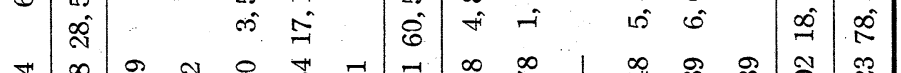
茂

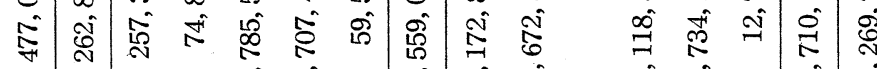
की ₹

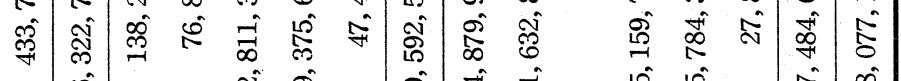
की की की है ণ্ণ

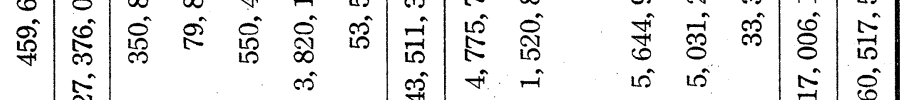
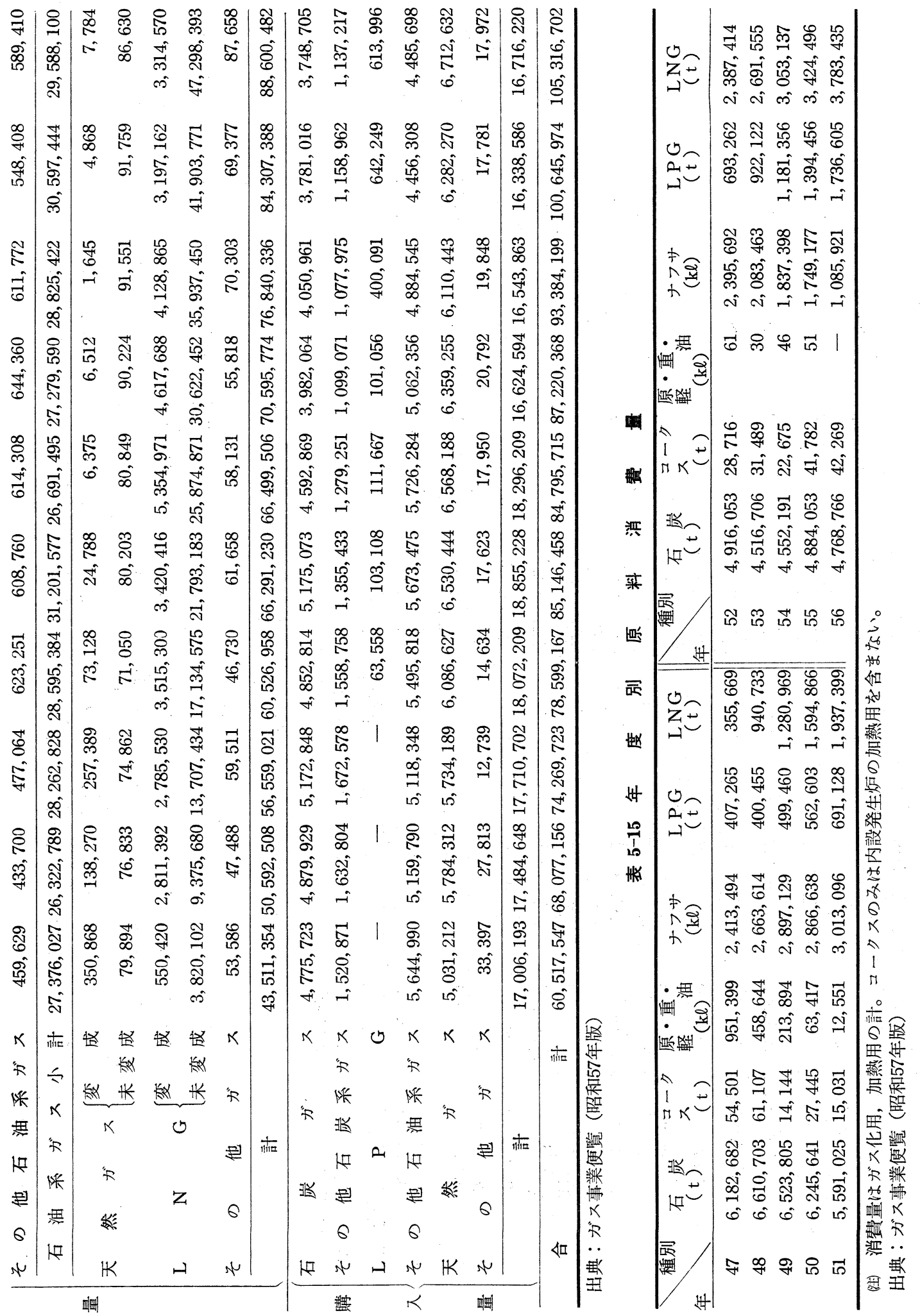


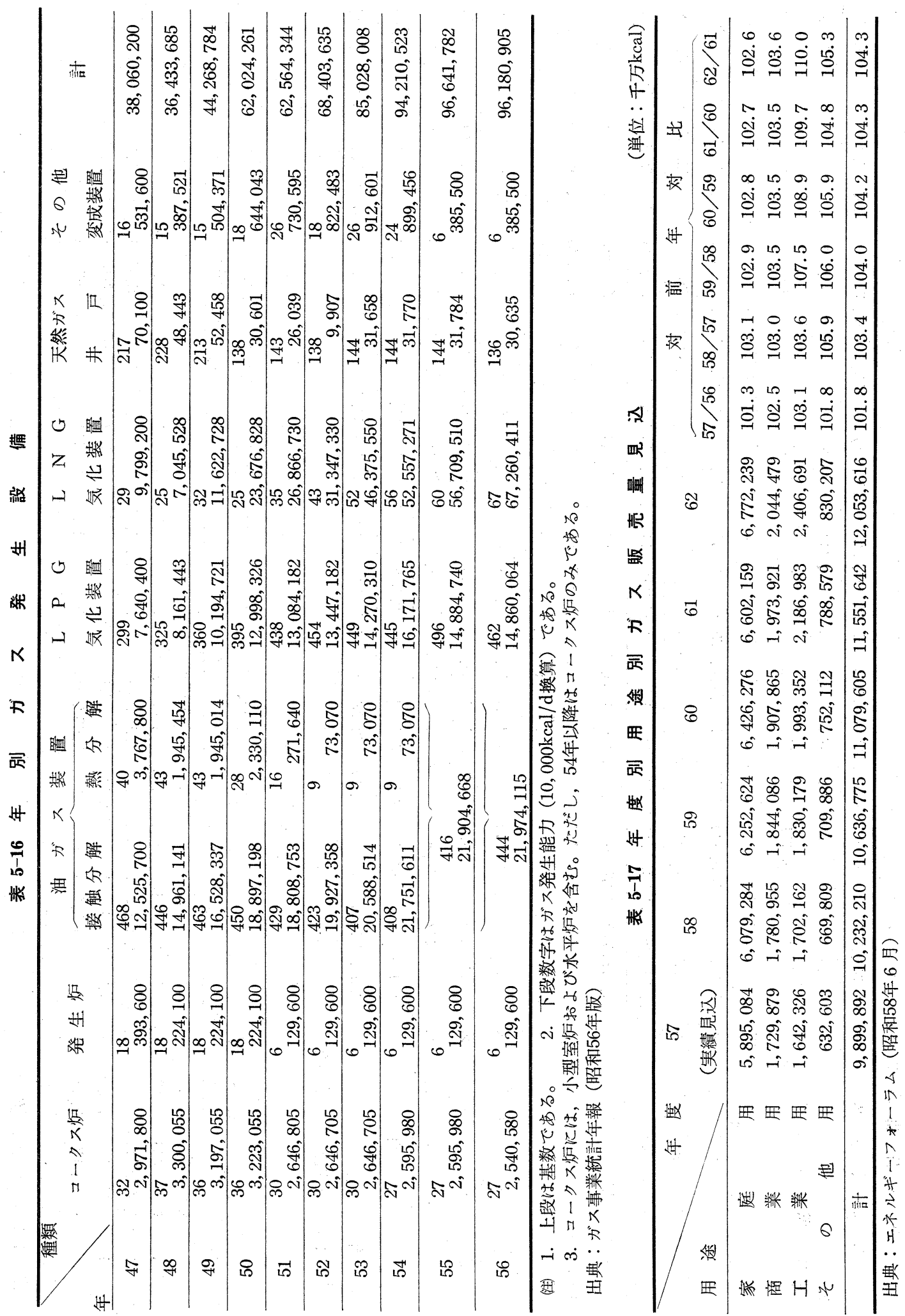




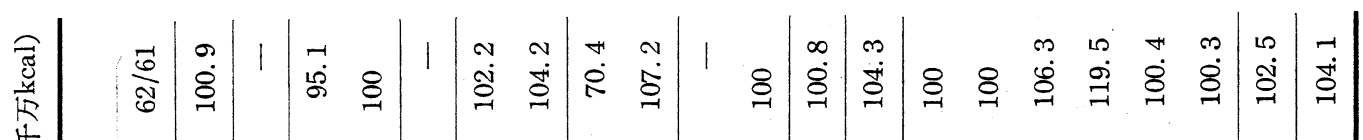

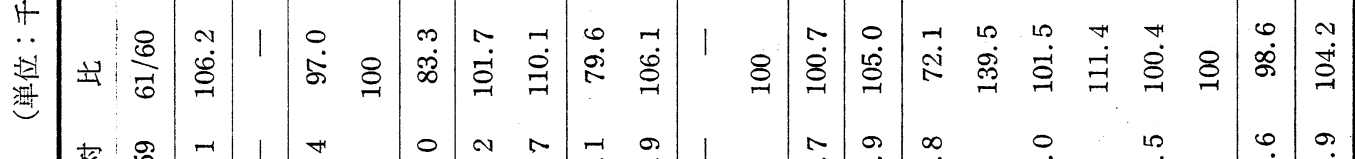

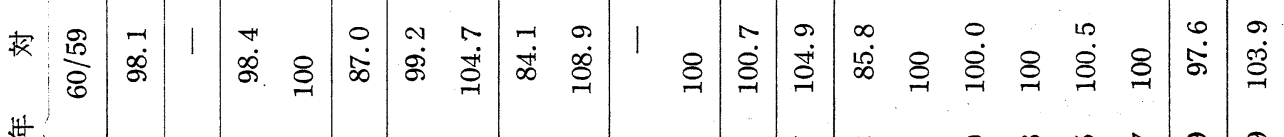

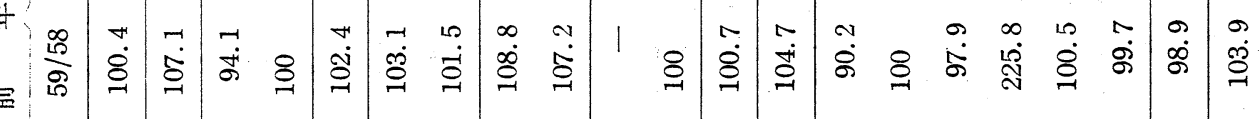

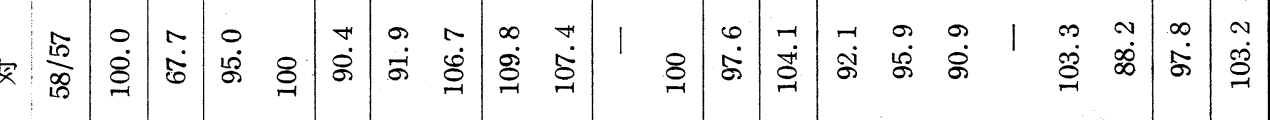

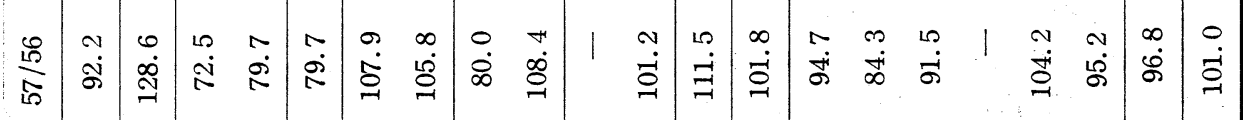

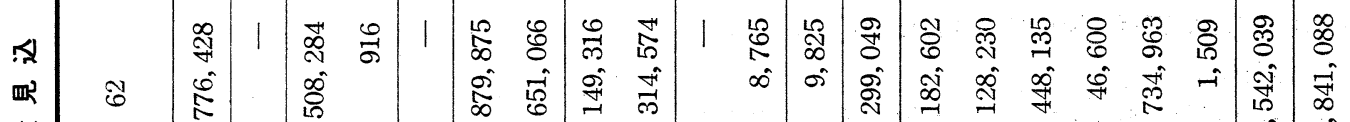

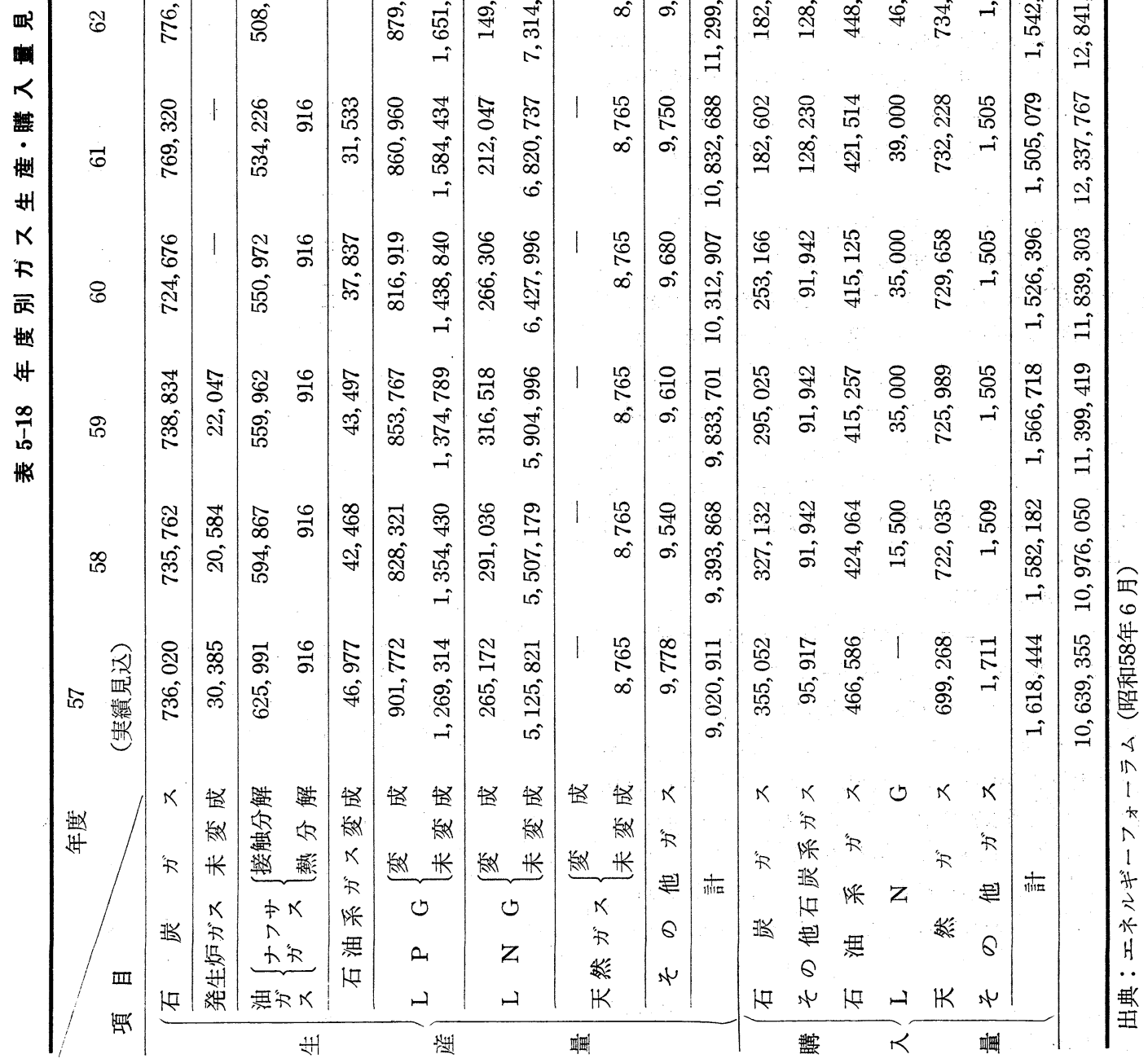


すなわち，L NGを電力事業者との共同体制のもと で昭和 44 年導入以来, 積極的にその導入拡大を四り,そ の結果昭和57年度には, 都市ガス事業に括ける L N G の使用量は 400 万江達し都市ガス生産量の $50 \%$ を占め るに致った。

\section{2. 都市ガス事業の現状}

\section{1 事業規模}

昭和 57 年 12 月末現在の一般ガス事業者は私営 175 , 公営73の合計 248 社となっている。しかし，その事業 規模は地域によって大きな差があり，需要家数で見る と50万件を超える需要家を有する事業者は東京ガス, 大阪ガス，東邦ガス，西部ガスの 4 社のみであり， 4 社合計で全需要家数の $72.5 \%$ を占めている。また全事 業者の $63 \%$ ，需要家数 10,000 件未満の事業者であ る。都市ガスの普及率は昭和56年12月末現在の供給区 域内世帯数 2, 200 万戸に対し $77.5 \%$ となっている。

\section{2 需要構造}

需要家数は昭和 56 年度末で 1,715 万件に達し前年度 末から 50 万件の増加を見た。過去 10 年間の平均伸び率 は $4.4 \%$ でその伸び率は低下する傾向にある。

ガス販売量は昭和 56 年度末 97 億 $\mathrm{m}^{3}$ (1万 $\mathrm{kcal} / \mathrm{Nm}^{3}$ 換 算）であり，景気の低迷，省エネルギーの徹底，他然 料との競合の激化の中で工業用の伸び，家庭用の伸び に支えられて底固い伸びを示した。

また用途別に見ると民生用の占める割合が大きく， 需要家数では99.7\% (家庭用 $93.6 \%$, 商業用 $5.2 \%$, その他 $0.9 \%$ )，ガス肘売量では $83.6 \%$ (家庭用 $59.9 \%$ ， 商業用 $17.3 \%$ ，その他 $6.4 \%$ ）を占めている。工業用 需要は需要家数, ガス販売量とも昭和 53 年度以降增加 に転じているが，これは一定使用条件下に括ける産業 用 L N G料金制度の普及が大きく影響しているものと 思われる。

\section{3 原料の構成}

昭和56年度の都市ガス生産, 購入量は 105 億 $\mathrm{m}^{3}$ （1万 $\mathrm{kcal} / \mathrm{Nm}^{3}$ 換算) であり，原料別構成比は L N G $48 \%$, L P G19\%, ナフサ $8 \%$, 石炭 $8 \%$, 天然ガス $1 \%$, 購入ガス $16 \%$ となっている。これを過去10年間の原料 使用量の推移から見ると石炭, コークスの使用量は漸 減し, 石油系原料の中では, まず原・重・軽油からナ フサヘのシフトが起こり引き続いて L P Gヘシフトさ れていったことがわかる。その結果，都市ガス原料の 中に占める石油系原料の割合は L NGの大規模導入と ともに着実に低下し昭和 56 年度では L P G, ナフサ, 石油系購入ガスを合わせた石油系エネルギーへの依存 度は $32.9 \%$ にまで低下した。一方, 石炭, 石油系原料

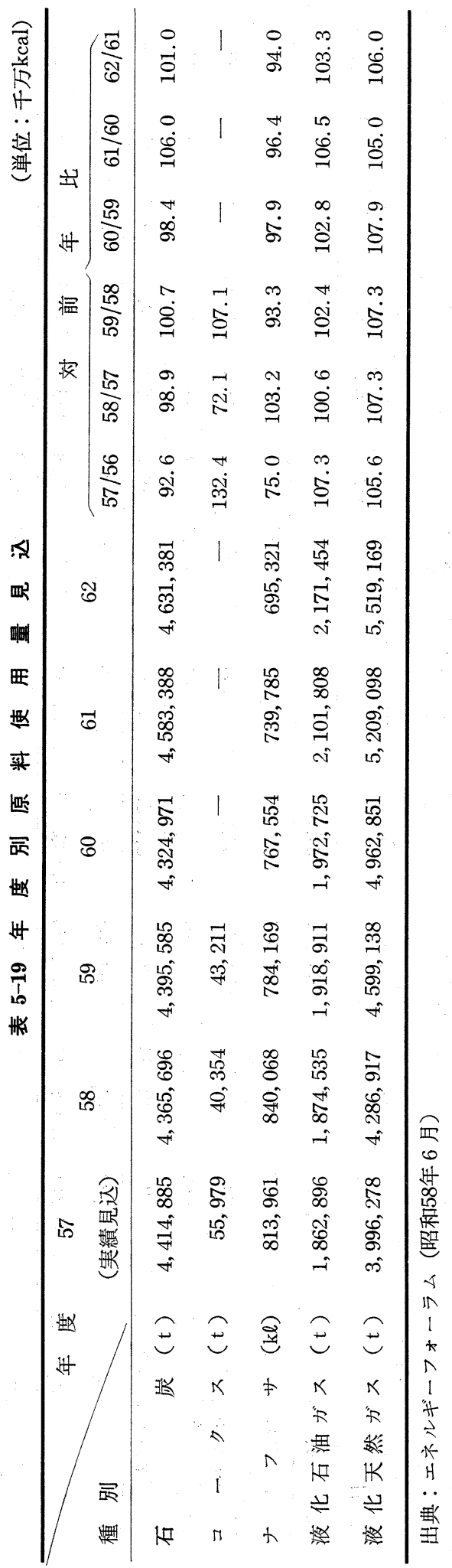


の使用量の減少の中で L N Gは相次ぐプロジェクトの 導入により順調な伸びを示し，57年度には，その構成 割合は50\%を越えたと見られている。

な抗これらの推移を裏付けるるのとしてガス発生設 備の推移がある。この中では L NG気化装置の大幅な 設備増強が特徵的な傾向となっている。

\section{3. 都市ガス事業の今後の展望}

\section{1 需要動向}

景気の低迷，省エネルギーの徹底，他燃料との競合 の激化の中で，これまでの家庭用需要の伸びを牽引力 とするパターンから工業用，商業用需要の伸びを中心 として都市ガスの需要を拡大していくことが期待され ている。

中でも工業用需要については, 都市ガスの有する。 高い総合熱効率，無公害性，安定供給性などに高い評 価が与兄られて抢り，諸外国に比べて都市ガスの利用 率のきわめて低いこの分野での需要拡大は産業用 L N G料金制度の導入と相まって大いに期待されている。

またその他の用途の中では冷房の普及拡大が見込ま れている。都市ガスによる冷房は，これまで地域冷暖 房，大規模ビル冷暖房を中心に普及が図られてきた が，今後は中・小規模の冷房需要分野への普及が不可 欠であり, 小型高効率吸収式冷暖房機, ガスエンジン ヒートポンプの開発が行われている。

\section{2 原料の動向}

現在，都市ガスの原料はL NG，L P G，ナフサ， 石炭，天然ガスなど多岐にわたっているがその中でも L N Gの比率は年々増加している。

L NGの導入は現在，東京ガス，大阪ガス，東邦ガ スの 3 社を中心に行われて和り，3社に拈いては供給 ガスの天然ガスへの変更作業を実施中であり, 工業用 需要の増加，ガス冷房の普及拡大とあわせて L N Gの 利用量は着実に増加するものと考光られる。

一方， 3 社を除く地方ガス事業者についてもパイプ ライン，タンクローリー，タンカーによる二次輸送に よる L NGの導入が真剣に検討されており，これらに よって, 昭和 62 年度の $\mathrm{L} \mathrm{NG}$ の使用量は 550 万 $\mathrm{t}$, 原料 の構成にしめる割合は $58 \%$ に達するものと考えられて いる。

また，石炭については横這いの傾向が続き，ナフサ からL P Gへのシフトの傾向もL P G 需給の逼迫化の 影響などにより一段落するものと思われる。

\section{3 合成ガス製造の動向}

\section{1. 一般情勢}

1.1 アンモニア

原料高, 市況不況からアンモニア国内消費実績が伸 びない状態は今年度 (57年度) も相変わらずであった。 56 肥年度の消費実績は肥料用が前年度比 $15.2 \%$ 減, 工 業用が $1.3 \%$ 増で, 結局, 生産は合計で $9.3 \%$ 減の 210 万 $\mathrm{t}$ 台になった ${ }^{1)}$ 。57年度 200 万 $\mathrm{t}$ 台を維持するには 当初工業用途向けの需要の伸びにかかってくることに なるとみられていたが，すでに57肥年度上期（7～12 月）で消費は 100 万 $\mathrm{t}$ を割り込んだ。この原因は肥料 向けが輸出不振のため大幅に落ち込んだことと, カプ ロラクタムなどの市況不振による。後でみるように， アンモニアを原料とする誘導品は国内アンモニアの高 価格のため，生産は停滞ないし，減少して和り，これ がは视返ってアンモニア消費の減少となっている。

57 年度もナフサ単独使用による原料コストの不利を 回避するために，原料転換がさらに進行した。生産各 社共, ブタン, プロパン, オフガス使用可能体制がほぼ 57年度中にできあがる予定であり, 最後のナフサ単独 使用プラントになる三菱化成黒崎も，58年春に L P G への転換が行われるといわれている。

その中にあって，宇部興産は共同出資会社である宇 部アンモニアに扮いてテキサコ法石炭ガス化プラント 建設のための技術導入契約を行い, 新体制でアンモ二 ア $1,000 \mathrm{t} / \mathrm{d}$ 規模で生産操業を 59 年に開始することに なった2)。原料の歴青炭はカナダから輸入するもので 石炭ガス化アンモニアプラントとしては世界最大規模

\section{表 5-20 アンモニア，尿素の生産量・需要推移} (万t $/$ 年)

\begin{tabular}{|c|c|c|c|c|c|c|c|}
\hline \multicolumn{4}{|c|}{ アンモニア } & \multicolumn{2}{|r|}{ 尿 } & \multicolumn{2}{|l|}{ 素 } \\
\hline \multirow[b]{2}{*}{ 肥年 } & \multirow[b]{2}{*}{ 生産 } & \multirow{2}{*}{$\frac{\text { 需 }}{\text { 肥料 }}$} & \multirow{2}{*}{$\frac{\text { 要 }}{\text { 工羛業 }}$} & \multirow[b]{2}{*}{ 生産 } & \multicolumn{2}{|c|}{ 需 } & 要 \\
\hline & & & & & 萌料 & 通業 & 輸出 \\
\hline 52 & 284 & 124 & 161 & 176 & 28 & 43 & 119 \\
\hline 53 & 290 & 125 & 165 & 192 & 29 & 51. & 120 \\
\hline 54 & 287 & 124 & 164 & 183 & 31 & 49 & 94 \\
\hline 55 & 235 & 98 & 140 & 142 & 20 & 41 & 79 \\
\hline 56 & 214 & 78 & 138 & 118 & 22 & 45 & 61 \\
\hline
\end{tabular}

58 年肥料要覧（アンモニアは通産省資料）より 
表 5-21 アンモニア原料源別製法能力

（千t/年）

\begin{tabular}{|c|c|c|c|c|c|}
\hline 年／月 & $53 / 4$ & $54 / 4$ & $55 / 4$ & $56 / 4$ & $57 / 4$ \\
\hline 原 & 260 & 261 & 122 & 122 & 122 \\
\hline ナ フ & 2,009 & 2,002 & 1,937 & 1,607 & 495 \\
\hline L P G, 石油廃ガス & 1,742 & 1,741 & 1,229 & 1,229 & 1,426 \\
\hline L P G, ナフサ & - & - & - & - & 914 \\
\hline 天 然 ガ ス & 503 & 501 & 358 & 358 & 358 \\
\hline コークス炉ガス & 53 & 54 & 55 & 55 & 55 \\
\hline 合 & 4,567 & 4,559 & 3,701 & 3,371 & 3,371 \\
\hline
\end{tabular}

58年肥料要覽（通産省資料）より

のものになる。宇部アンモニアとしてはナフサからL PGへ，そしてさらに石炭原料へと進行することにな る訳であり，注目されるところである。

石油以外原料としては他に, マレーシア・アンモニ ア計画のように海外立地で, 天然ガス原料のアンモニ ア計画も試みられている3)。

54 年，特定不況産業安定臨時措置法（特安法）飞基 づき，過剩設備処理が行われた。実績はアンモニア， 尿素それぞれ，119 万 $\mathrm{t}$ (処理率 26\%)，167万 $\mathrm{t}$ (処理 率 $45 \%$ ）であった。今回，57年 6 月産業構造審議会化 学工業部会答申を受けて，60肥年度までにアンモニア 66 万 $($ 処理率 $20 \%$ ), 尿素 83 万 $\mathrm{t}$ (処理率 $36 \%$ ）の設 備廃棄縮小が進められることになる。前回は長期休止 中のプラントの処理で対処されたが，今回は，稼働中 のものについて行われることになるので，コンビナー 卜内での調整を考慮しつつ, 縮小改造（三菱化成 1,000 $\mathrm{t} / \mathrm{d} \rightarrow 800 \mathrm{t} / \mathrm{d}$, 鹿島アンモ $=>950 \mathrm{t} / \mathrm{d} \rightarrow 800 \mathrm{t} / \mathrm{d})^{4)}$ p, 集中生産体制の方法が採られることになる。58年 1 月 現在，90\%程度の達成になっているといわれている。

アンモニア不振は，基本的には輸出用尿素向汁が振 わないことによる訳で，50年に工業用，肥料用の消費 比率が逆転して以来，56年には工業用 7 割，肥料用 3 割迄になっている。すでに尿素については輸出40万 $\mathrm{t}$ 体制を目途とし，内需主導の方向が打出されている。 その他のアンモニア誘導品として，タイアュード不況 のためカプロラクタムが悪く（三菱化成は減産方針 を打出した ${ }^{5)}$ )，アクリロニトリル，ソーダ灰(アンモ ニアソーダ法) なども原料アンモニアのコスト高のた めに価格競争力が圧迫されている。アクリロニトリル は56年にすでに入超に転じている。東洋曹達は, ソー ダ灰・塩安併産法に沶いて，アンモニア製造原料を $\mathrm{L}$ $\mathrm{NG}$, 残さ油，ピッチに切りかえたり，塩安分解によ りアンモニア回収再利用を検討している。また，アン
モニア生産が中止された場合にはアンモニアプラント が荷っている，コンビナート内での $\mathrm{CO}$ ガス供給の問 題解決がはかられる必要があるといわれている6)。

57年も省エネルギーをめざしたアンモニア合成プロ セス開発の研究が行われている。モンテェジソン社は 高活性新触媒の開発により, 従来のエネルギーコスト の $80 \%$ 程度になることが期待されるアンモ二ア合成プ ロセスのプロジェクトを発足させた。これはE E Cの 援助を期待しているもので, $50 t / d$ 実験 プラントが 1983 年初頭から始まる予定である7 。ICI も同様に, 新触媒開発により，70 80気圧で天然ガス原料を用い る $\mathrm{AMV}$ 法プロセスの売り込みを検討している。カナ ダ (オンタリオ州) の 40 万t/年プラントは $\mathrm{AMV}$ 法プ 口セスを採用する最初のものであり，1984年運転開始 予定となっている8)。

\section{2 尿 素}

57 肥年度上期 ( $7 \sim 12$ 月) は, 内需 $4.4 \%$ 增であっ たが, 生産は $18.5 \%$ 減となり, 在庫は $42.6 \%$ 減となっ た9)。これは前年度に比較し, 横ばいの結果である。 56 肥年度については, 内需 $7.2 \%$ 増加 (80万 $\mathrm{t}$ ), 輸出 $22.5 \%$ 減 $(61$ 万 $\mathrm{t}$ ), 合計で $8 \%$ 減となり, 一方, 生 産は前年比 $15.7 \%$ 減 (131万 t ) となり, メーカー各

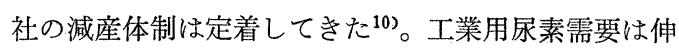
長したと同時に，8/1出荷分からの10円值上げが，55年 春以来決着した。

最盛期には 200 万七のぼった中国向け尿素輸出は 56 肥年上期 35 万 $\mathrm{t}$ の実績であったが，56肥年下期交渉は なかなか進展せず，10月に入り, 数量大幅ダウンの 10 万 $\mathrm{t}$ 強の結果となった。 57 年は硫安輸出会社解散を受 けて，11月に，長期的飞安定した輸出秩序の維持を目 的として, 肥料輸出組合の設立総会がもたれた。工業 用尿素については, 尿素の共同輸入構想が検討されて いる。 
アンモニアの項でも述べたように，6月産業構造審 議会化学工業部会答申を受けて，化学肥料工業は構造 改善へ向けた具体的実施段階に入った。尿素は 60 肥年 度までに 83 万 $\mathrm{t}$ 処理が目標で, 目標が達成されると輸 出 40 万 $\mathrm{t}$ とした時, 操業率は 80 数\%になるものとみら れている。生産受委託されるのは, 昭和電工 $\rightarrow$ 鹿島ア ンモニア, 住友化学 $\rightarrow$ 三井東圧で, 日産化学は 1 系列 が休止される。これだけで，目標值83万 $\mathrm{t}$ の $52 \%$ の処 理達成になると見込まれている11。

モンテェジソンは省エネタイプ ID R 法尿素コマー シャルプラント・テストを完了し，スチーム消費量を 40\%削減したと伝えられる12)。これにより，スチーム 原単位は，0.5t/t尿素になるわけで，これは三井東圧 /東洋エンジニアリング A C E S と同程度で, プロセ ス的に細部が異なるものの，尿素プロセスに打沙る省 エネ化は一段落したと考壳られる ${ }^{12)}$ 。バルク・ブレン ド用大粒尿素の需要が高まっているが，三井東圧は， 3 万t $/$ 年規模の噴流床式大粒尿素製造プラントを企業 化した ${ }^{13)}$ 。

1.3 ×タノール

メタノールは，アンモニアと並ぶ合成ガス用途であ る。 $\mathrm{C}_{1}$ 化学体系に捻いて製品でもあり，原料でもある メタノールは重要な位置を占めている。発電用, 自動
車燃料あるいはオクタン価向上剤として将来性が見込 まれている。その一方で，具体的な先行きとなると， 市場規模の桩大の様子, 石油, 天然ガス価格とのかね あいにより，供給過剩となることも繋念されており， 先行きに不透明さがある。国内需要は56年は国産72万 $\mathrm{t}$, 輸入 33 万 $\mathrm{t}$ で計 105 万 $\mathrm{t}$ であったが， 57 年は最終 的に100万tの大台を割り込むことが予想されている。 これは，あいかわらずの住宅不況で，ホルマリン向け 不振のためである。期待されている燃料向け実用化も 具体化には至らず，東西メタノールャンターのみなら ず，天然ガスベースの三井東圧，三菱瓦斯化学，協和 ガス化学も低ロード運転が続いている。表5-23に国内 メーカー実績を示す。

需要が伸びない中で, 国産品は輸入品に較べ変動費 ベースで10〜20\%割高のため，海外からのメタノール 輸入は増大して和り，57年には50万 $\mathrm{t}$ にのぼり，近い 将来には，予定され，かつ一部すでに入津している， サウジアラビア（日・サメタノール計画）やカナダ(ア ルバータ・ガス・ケミカル, セラニーズ, オセロット) などからの輸入により，80９0万輸入されると見达 まれている。

このように，国内に和けるメタノール供給の大幅過 剩感がある中で，業界からは特定産業構造改善臨時措

表 5-22 タノ一ル生産能力

（千t/年）

\begin{tabular}{|c|c|c|c|c|c|}
\hline メーカー & ガス源 & 53年 & 54年 & 55年 & 56年 \\
\hline 協和ガス化学 & 天然ガス & 132 & 132 & 132 & 132 \\
\hline 三菱ガス化学 & $" \prime$ & 396 & 396 & 396 & 396 \\
\hline 三井東圧化学 & " & 132 & 132 & 132 & 132 \\
\hline 東日本メタノール & $\mathrm{L} \quad \mathrm{P} G$ & 264 & 264 & 264 & 264 \\
\hline 西日本メタノール & $" \prime$ & 330 & 330 & 330 & 330 \\
\hline 計 & & 1,254 & 1,254 & 1,254 & 1,254 \\
\hline
\end{tabular}

メタノール・ホルマリン協会資料による。

表 5-23 メタノール国内メーカー実績推移

（千t/年）

\begin{tabular}{crrrrr}
\hline 年度 & 生産 & 輸入 & 内需 & 輸出 & 在庫 \\
\hline 53 & 870 & 145 & 1,015 & 58 & 78 \\
54 & 915 & 185 & 1,080 & 18 & 88 \\
55 & 821 & 156 & 940 & 14 & 114 \\
56 & 721 & 186 & 905 & 18 & 100 \\
$57^{*)}$ & 639 & 269 & 919 & 16 & 68 \\
\hline
\end{tabular}

*) 57 年は暦年

メタノール・ホルマリン協会資料による。
置法（構造改善法）の指定業種に認められることを望 む声がある。その一方で，東日本メタノールは，プロ パン，ブタン共に $75 \%$ 使用体制を可能にすると共に, 操業率 $80 \%$ を維持すべく，原燃料原単位向上，定修時 $800 t / d$ への移行などによる合理化を徹底している ${ }^{14)}$ が，4月～11月の長期操休に入ることになる。西日本 メタノールは 58 年 $4 \sim 9$ 月長期操休することを決め $た^{15)}$

東西メタノール・センターの間での輸番運転体制む 検討されている。また，すでに三菱瓦斯化学は 1 系列 
を休止させている16)。

メタノールにとって, 今後最も大きな関心は燃料用 メタノール市場の展開如何であろう。国内でも，メタ ノール基本問題研究会（メーカー十通産省）に上り燃 料用メタノール需要予測の検討が行われている。現 在, 世界的洪給過剩下にありながら, 大型計画が目 白押しなのは，燃料用あるいはガソリン添加用が見込 まれているからである。

メタノール法酢酸合成法は原料コストの有位性を生 かし, 国内に打ける瞃酸製造体制を塗り変えつつあ る。ダイセル化学 (協同酢酸) は輸入メタノールを原 料とし，57年フル操業となっていて，57年中にアセト アルデヒド法に代わり，主流をなすに至った。58年は 2 万千 $\mathrm{t}$ 能力アップして22万 5 千 $\mathrm{t} /$ 年体制になる ${ }^{17) 。 ~}$ 需要は 57 年度 40 万 $\mathrm{t}$ 程度なので, 酷酸ビニルモノマー 向解などが落ち込み，需要が低迷している中で，ア七 トアルデヒド法は苦境にある。これがきっかけとな り, メーカーの生産集約が進行し, 市況調整の効果も 出ているといわれる。

\section{4 オキソ法 ${ }^{18)}$}

今年度 (57年) は，ブタノール需要見通しは，可塑 剤, 塗料用, アクリル酸用, 酰酸ブチル用として昨年 並多水準 $(8$ 万 9 千 $\mathrm{t} /$ 年) で, 内需 8 万 4 千 $\mathrm{t}$, 輸出 3 千 $\mathrm{t}$, 計 8 万 7 千 $\mathrm{t}$ で出発したが, 可塑剤などの実 需面での手掛り難から，市況は低迷に推移した。

オクタノールについても主力の可塑剤, 溶剂向けの 盛り上りを欠き， 57 年 $4 \sim 6$ 月出荷は 1 万 2 千 4 千 $\mathrm{t}$ で前年同月を下回り，57年上実績としては10万 3 千 $\mathrm{t}$ であった。

オキソ合成に和いては57年もひき続き，コバルト触 媒がロジウム触媒へ置き換えられて和り, チッソ石油 化学は 57 年 7 月にロジウム触媒汇転換された。副生 ソブタノール供給は, この傾向の中で 3 万 $\mathrm{t}$ 供給が精 一杯とみられている。生成物残渣からのロジウムを回 収するプロセスの開発も続けられている。

生産受委託の形で, 昭和電工アセトアルデヒド法ブ タノールが，三菱化成オキソ法ブタノールに置き換え られた。

\section{2. 合成ガスの原料}

合成ガス製造プラントは，ナフサ単独使用生産態勢 から脱却する努力をしてきた。そのナフサについて長 年の懸案であった, 石化業界によるナフサ輸入権問題 が，57年 4 月通産省議決定により決着をみ，実質的に 石化業界は安価な海外ナフサ入手が可能になり, この 結果，57年はナフサ輸入が急增した。 57 年 $1 \sim 12$ 月の
ナフサ, L P G 輸入はいずれむ 2 桁增で，ナフサ 16.9 \% (1, 022万k $\mathrm{l}), \mathrm{L}$ P G $13.5 \%$ (1,174万 $\mathrm{t})$ となっ

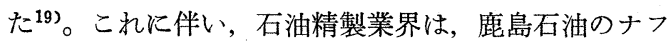
サ生産実質打切り（ナフサの全量を，高オクタン価ガ ソリンと B T X原料とする，また，コンビナート内で は必要ナフサは継続供給される) 203 の例にみられるよ らに急速にナフサ得率を低下せしめ，57年11月には初 めて $5 \%$ 台まで落ち込んだ。

58年に入って, O P E C の足並久の乱れから原油価 格は值下りし，ナフサ価格は低位に推移してきた。国 内に执いては，57年以前より，ナフサ単独使用を軽減 する目的で実施されてきた多種原料使用体制下，いま またナフサ使用体制へ切りかえられつつある。逆にL P G は原油減産の影響を受けて洒格が上昇し, 下降す るナフサと逆転した 211

\section{3. 合成ガス製造技術}

ケム・システムズ社の予測によると ${ }^{22)} ， 21$ 世紀以降 も原油価格との相対的関係から石炭からの合成ガス開 発は慎重になるべきだと，と言われている。ひとつに は合成ガスプラントが採算ベースに乗るためには 2 億 立方フィート/ $\mathrm{d}$ の大規模化が必要であり, 資本コスト が割高になるためである。この採算べースの決定要因 の最たるものは原油価格であり, 1990 年にこれが 100 ドル/bbl となれば合成ガスコストはたちらちできる とみられている。最近の原油価格の値下げによりいっ たん活発化した代替燃料, 原料の研究の沈静化を心配 する向きもあり，先行きの不透明感は依然残ってい る。

わが国に特いては，新エネルギー総合開発機構（N E D O）により，プロジェクトが進められている。従 来の流動床式石炭ガス化法に変え, 多品種の石炭の利 用，大規模化を可能にするため，噴流床方式が $200 t / d$ パイロットプラントで60年末までにデータ収集を行ら 予定である。また，石炭一重質油混合原料の加圧流動 ガス化方式を電源開発に委託していたが，連続運転の 目途がついた，と言われる。これと並んで，通産省は コークス炉ガス，高炉ガス，転炉ガスなどの製鉄廃ガ スを $\mathrm{C}_{1}$ 化学の原料とすることを検討することになっ た。これらオフガスは現状，大部分が自家消費されて いる。一部，水素製造用に用いられつつあるが，これ までの都市ガス，炭酸ガス，アンモニアなぞへの利用 は $5 \%$ 程度止まりである。技術的には，原料ガス組成 の多様化に対処する方法の開発が必要であり, 副生が スであることから安定供給がどこまで期待できるかと いう問題も㐫る。いずれにしても $\mathrm{C}_{1}$ 化学研究の進展 
と相まって，高付加価値品の原料となりらる訳で，製 鉄, 化学両業界の調整などを検討するため, 「製鉄が ス総合利用対策委員会」を設けることになった。オフ ガスの利用としては, カーバイド炉副生一酸化炭素ガ スの $\mathrm{C}_{1}$ 化学への利用検討も行われている。

開発輸入については資源エネルギー庁の委託で日本 エネルギー経済研究所が，インドネシアへ調查団を派 遣した ${ }^{23)}$ 。こはスマトラ島バンコ炭を原料としでガ ス化を行い, むってメタノール, アンモニア，尿素な どの化学プロジェクトの F S を実施するためである。

現在進行中の石炭ガス化計画としては, ルール・コ ーレ社の 25 万 $\mathrm{t}$ 石炭/年, クレックナー・ヴェルケ社 の100万 $\mathrm{t}$ 石炭/年, 宇部興産 $1,500 \mathrm{t}$ 石炭/ $\mathrm{d}$, ダウ・ ケミカルの400t/d他があり，TVAにおいてはテキサ コ法（部分酸化）石炭ガス化プラントが57年初めてア ンモニアプラントに合成ガス供給を開始した ${ }^{24)}$ 。

ハルコンSDグループとイーストマン・コダックは 貴金属を使用しないでメタノールと一酸化炭素から無 水眽酸を製造するプラントを 58 年にテネシー州に 22 万 $\mathrm{t} /$ 年規模で稼働する予定であり,メタノールと一酸化 炭素は石炭ガス化により供給される25)。変わったとこ ろでは改質剤として水蒸気を用いる代わりに二酸化炭 素にてL P G改質を行い, 水蒸気改質法では通常一酸 化炭素濃度が20 30\%のところを $70 \%$ 程度のものを得 る新プロセスが報告されている26)。水素はP S A 法に て分離され, 最終的には $99.5 \%$ 濃度の一酸化炭素ガス を得る。これは一酸化炭素の高濃度を生かし，ホスゲ ン製造用原料として検討されている。

\section{4. 水 素}

わが国の水素ガス外販は 7 千万 $\mathrm{m}^{3} /$ 年で, 原料ガスは カセイソーダ業界の副生水素が 9 割程度である。現状 の合成ガス製造能力からすれば小さい市場であるが, 水素は原料としても，また，エネルギー形態としても 将来性が期待されている。この方面の水素は現在は, 油脂工業水添用, 金属・ガラス工業, エレクトロニク ス関係で使用されているが, 中でる半導体向けはここ $2 \sim 3$ 年の間，年率 $20 \%$ 以上の伸びになっていて， 57 年度中, 市沉はタイトに推移した。

製鉄炉ガスを有効に利用する形で，すでにプラント が稼働しているのは, 日本鋼管, 住友金属などがあり, 58年プラント完成が見込まれているものに, 新日鉄広

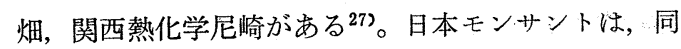
社のプリズム・セパレーター方式（膜分離方式）水素 精製装置を住友化学へ納入した（処理能力 2 万 $\mathrm{m}^{3} / \mathrm{h}$ ) 28)。合成ガス，オフガス原料以外でも，NEDOサン
シャイン計画の一環として, 水の電解法, 熱化学的方 法, 光分解に上る水素製造技術の開発研究が行われて いる。丸谷化工機はメタノール水蒸気改質法と P S A 法を組み合わせた水素製造装置を開発した ${ }^{29}$ 。

技術的には，精製分離，貯蔵，輸送についての手段 が研究されていて, 現在, その方法のひとつである水 素貯蔵合金の 開発研究はピークにあるといわれてい る。岩谷産業は,インコ社グループから生産委託され たミッシュメタル・ニッケル系を吸蔵剤として用いる 水素輸送コンテナを開発した ${ }^{30)}$ 。

$\mathrm{LaNi}, \mathrm{FeTi}, \mathrm{Mg}_{2} \mathrm{Cu}$ などの金属水素化物を用い る方法で, 従来は吸着理論值(約 $1 \mathrm{~g}$ 水素 $/ 100 \mathrm{~g}$ 金属水 素化物）の76\%であったのが最近 $85 \%$ まで向上したと いわれる31)。エア・プロダクッ社は，水素を，オフガ ス流から回収し，99モル\%純度のものを得る方法を開 発した。現在アンモニア・プラントにて水素回収パイ ロットプラントを運転中である。水素の吸着脱離は $\mathrm{P}$ S A 法で行われる。この方法は断熱下, 吸着を加圧条 件にて行い, 脱着を減圧条件にて行うもので, 熱の出 入りが大幅に減じられ, 加熱による水素の脱着方法に 較べると経済性が高いと言われている。

他の水素分離精製方法としては, 実用化されている 極低温分離, モレキュラーシーブP S A法, 中空系分 離などがある。

\section{5. $\mathrm{C}_{1}$ 化学}

通産省工業技術院シーワン化学技術研究組合は, 触 媒の 1 次スクリーニングを終党, 当初目標值を達成し た，エタノール，炭化水素，エチレングリコールにつ いて，58年度からベンチテストの研究に入ることにな った。ベンチ装置完成は 59 年と見込まれている。電気 化学はカーバイド工業副生ガスを利用し, マロン酸エ ステルの低圧法新プロセスを開発，従来の青酸法マロ ン酸設備を転換することになった ${ }^{322}$ 。

従来法である眽酸製造の際の副生物としてのギ酸の 製造方法代代わり，一酸化炭素，水，メタノールなど からの製造プロセスが開発されてきたが333，フィンラ ンドにおいて，レオナードプロセスにより 2 万 $\mathrm{t} /$ 年 の工場が立てられ, 操業が開始された ${ }^{34)}$ 。このプロセ スは第 1 段階でメタノールと一酸化炭素からギ酸メチ ルを生成させ，引き続き加水分解させてギ酸を得るも のである。アルゴンヌ国立研究所は，新触媒を用い， メタノール, 水素, 一酸化炭素から無水エタノールを 製造する方法を開発した。従来は, 反応生成物として 水が副生するため, 無水物を直接に得ることがでさな かったもので新法によると水の代わりに二酸化炭素が 
副生する。さらに，酢酸エステル，アセタールなどの 副生がないともいわれている ${ }^{35)} 。$

$\mathrm{C} 1$ 化学の鍵はまず安価な合成ガスが入手できるこ とであり，並んで有効な触媒の開発にある。貴金属触 媒に代わる卑金属触媒の開発の必要性, 原油, 天然ガ ス価格の動向との関係などいくつかの問題点が指摘さ れながらも，ここまで進行した原料の多様化指向の流 れはひきつづき, 強力に展開されていくものと思われ る。

\section{文 献}

1) 化学工業日報, 57.8.19

2) 同上, 57.12 .14

3）同上, 57.5 .15

4) 同上, 57.5 .12

5）同上, 58.1.29

6) 同上, 57.8.21, 57.12.22

7) European Chem. News, Aug. 30, p. 18

8）同上, Nov. 22, p. 24

9）化学工業日報, 58.2.17

10）同上，57.8.13

11）同上, 57.4.14, 57.9.7, 58.1.1

12) 同上, 57.11.1

橋本, 他, アンモニアと工業, 35，(3)，7

13）化学工業日報，58.2.4

14）同上, 57.11 .30

15）同上, 58.1.18, 58.2.22

16）同上, 58.1 .18

17) 同上, 58.1.7

18）同上, 57.5.29, 57.10.15, 58.3.30

19）同上, 58.2 .16

20) 同上, 58.2.3, 58.2.8

21）同上, 58.2.15

22) Chem. Eng. News, Mar, 29, p. 28

23）化学工業日報, 58.2.3

24) Chemische Industrie, July, p. 448

European Chem. News, Sep.27, p. 22

Chem. Week, May. 19, p. 70

25) Kohn, P. M., et al., Chem. Eng., May 3, p. 39

26) European Chem. News. Mar. 22, p. 21

27）化学工業日報，57.7.1

28）同上，57.12.7

29）同上, 57.8.4

30) 同上, 57.6.1

31) Kaplan, L. J., Chem. Eng., Aug. 9, p. 34

32）化学工業日報, 57.8.6

33) Kaplan, L. J., Chem. Eng., July 12, p. 71

34) European Chem. News, Apr. 26, p. 14

35) Chem. Eng. News, Sep. 20, p. 41

\section{4 液化石油ガスの動向}

\section{1. 昭和57年度の需給動向}

昭和57年度の需給動向は上期と下期ではまったく別 の様相を呈した。上期は輸入状況も順調であり，需要 も年度初通産省が策定したL P ガス需給計画の線に沿

って進んだので，比較的平穏であった。ただ為替の円 安傾向による原価上昇と決済差損を売価に転稼しきれ なかった元売業者は赤字に悩んでいた。下期にはいっ てもしばらくは同様であったが，12月以降は一転して 輸入が異常に減少し，せっかくの需要を自ら削減せざ るを得ないといら異常事態となった。この輸入減の原 因は，中東石油情勢の激変によるものであった。夏以 降，世界的石油需給緩和のしわよせがサウジアラビア に集中し，サウジは原油生産量を次第に低下させざる を得なかった。ところが，原油生産量が減少すれば， 原油随伴ガスから回収される L P ガス生産量も減少す る。したがって，サウジアラビアの L P ガス輸出能力 は月を遂って低下していった。しかるに，わが国の L $\mathrm{P}$ ガス総供給量の内約 $70 \%$ は輸入であり，その輸入量 の内約 $60 \%$ はサウジに依存しているのだから，その減 少がわが国に与える影響は大きかった。12月に入ると 供給不足必至, 先行皆目不明といら状況となった。こ の状態は年度末に至っても解消しなかった。政府も業 界もこの対策に懸命となった。他の原然料と一時的に 代替の利く用途，たとえば石油化学原料，電力用，都 市ガス用などは大手企業に対して通産省が一時転換を 要請, 業界は納入辞退するなどの非常手段をとった。 またスポット輸入に奔走し，通常は輸入を行っていな いアメリカ,メキシコなどより緊急輸入を行った。こ れらの努力の結果, 何とか下期需給をきりぬけること ができた。しかし，マーケットに与えたマイナスの影 響は大きく，今後長期間後遺症が残ることであろら。

\section{2. 昭和58 62年度 $L P$ ガス需給計画}

5 月 24 日開催された石油審議会で昭和 58 年以降 5 年 間の L P ガス需給計画が表5-24のと和り了承され，確 定した。57年度上期需要は前年同期比 $111 \%$ であった のに, 下期需要は $100.4 \%$ と横這いになったのは，需 要削減効果が80万 $\mathrm{t}$ 位あったことを示しているすのと 考えられる。この需要削減は58年度にも影響し，上期 需要は前年対比 $87 \%$ とい著しい低落が予想されてい る。下期需要はいくらかは回復して前年同期比 $98 \%$ と 
表 5-24 昭和58〜62年度 L P ガス需給計画

(単位: 千 $\mathrm{t}$ )

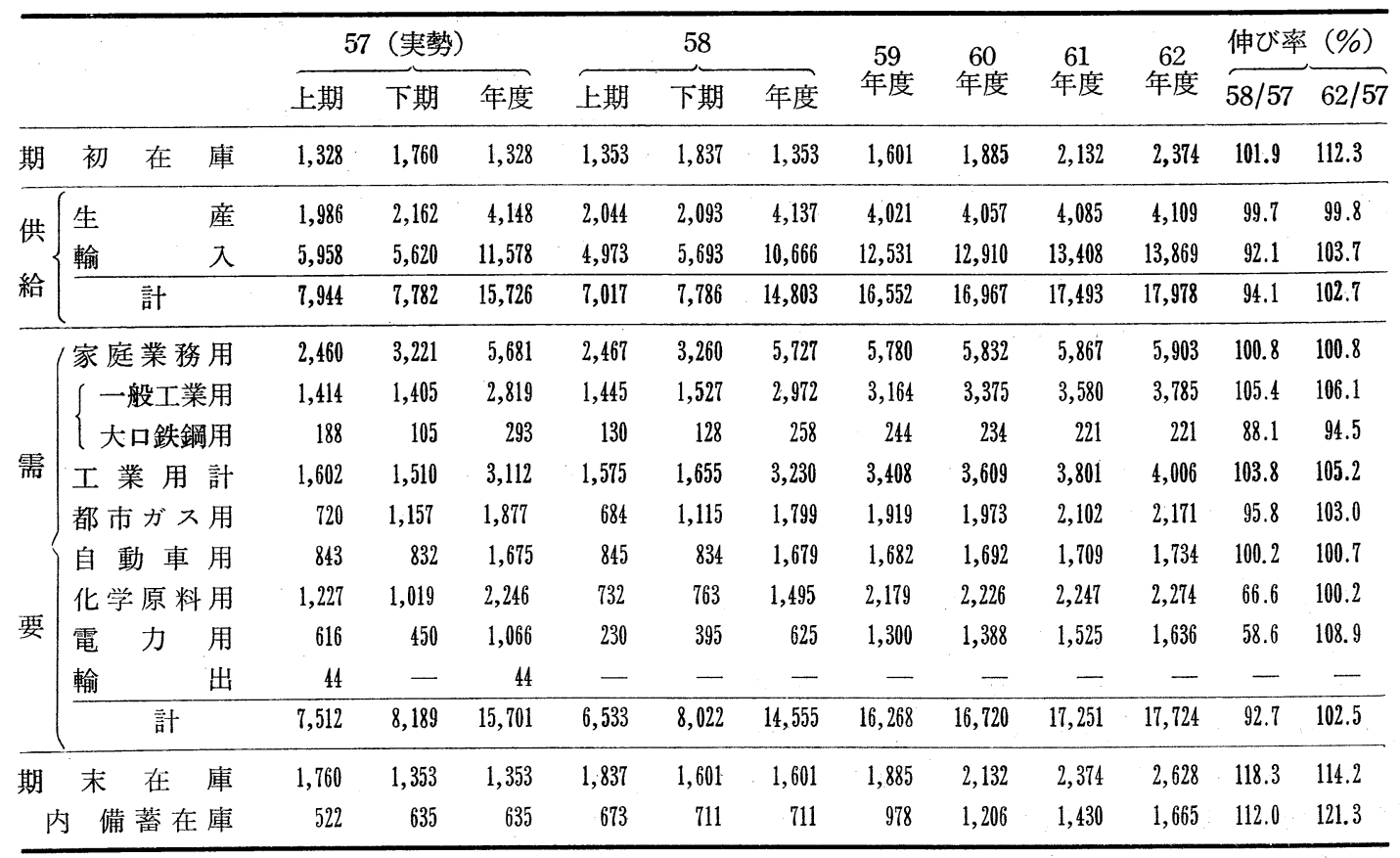

想定されており，58年度全体では57年度比 $92.7 \%$ と減 少, 需要規模は 2 年半逆戻りしている。計画段階で前 年度を下趈る需要想定が行われたのは L P ガス業界始 まって以来のことである。59年度以降の長期について は, 一応供給状況が安定し, 価格も競合品と競争でき る価格になるといら前提で需要が想定された。そのた め, 59 年度には大幅の戻り需要があり, 58 年度対比 $111.8 \%$ 伸びるが, 60 年度以降は年率 $3 \%$ 程度の伸 びに拈らつくといら姿になっている。なお，昨年度の 需給計画の昭和 61 年度需要 18,893 千 $\mathrm{t}$ と比較すると今 回の計画の 61 年度需要は 17,251 千 $\mathrm{t}$ で, 1,642 千 $\mathrm{t}$, $8.7 \%$ の計画下方修正となっている。

それぞれの用途については，家庭業務用は微増，一 般工業用は景気の回復と L P ガスへの燃料転換に支え られて毎年 $106 \%$ 程度の伸び，大口鉄鋼用は脱ガス傾 向の進展につれて減少, 都市ガス用は大手の L NG化, 中小の L P ガス化がさらに進んで 103\%台の伸び, 自 動車は一般車の L P ガス化が今後進むとみて $101 \%$ 台 の伸び, 化学原料用は競合価格が可能ならば59年度に 急激に戻り, 後は $101 \%$ 程度の伸び, 電力用は計画中 の L P ガス火力が予定通り建設稼働するとして $108 \%$ 程度の伸びをそれぞれ長期的に想定している。

また，輸入量については56年度は供給量中71.3\%， 57 年度は73.6\%を占めていたが，58年度は72.0\%と一
休みする。長期的には 62 年度は $77.1 \%$ をて再び上昇す ると計画されている。58年度の輸入については, 不透 明であり，予断を許さないが，下期には一応の扔らつ きをみせるものと思われる。

なお，本年も夏頃を目標に, 総合エネルギ一調查会 が今後の政府のエネルギー政策の指針となる「長期エ ネルギー需給見通し」を改定発表する予定で, 現在作 業中とのことである。その中でL P ガスは従来通り石 油代替エネルギーに準ずる立場となっており, その数 量は昨年発表された「見通し」中で昭和65年度の需要 を 2,400 万 $\mathrm{t}$ みているのに対し, 今回は65年度需要を 2, 000万t程度と見达むものと予想されているが，これ は 400 万t, $16.7 \%$ の大幅下方修正となる。

\section{3. 昭和59 62年度石油ガス備蓄目標}

同日の石油審議会で昭和 59 年度以降 4 年間の石油ガ ス（L P ガス）の備蓄目標が了承され, 石油供給計画 と同じく翌25日官報で告示された。

\begin{tabular}{|c|c|c|}
\hline 昭和 59 年度 & (25日分) & $711 千$ \\
\hline $60 \prime \prime$ & $(30 \prime \prime)$ & 978 \\
\hline $61 " \prime$ & $(35 \prime \prime)$ & 1,206 \\
\hline $62 \prime \prime$ & $(40 \prime \prime)$ & 1,430 \\
\hline
\end{tabular}

これは 58 62年度需給計画の輸入数量を基礎に計算 されたものである。備蓄法によって常時保有が義務づ けられているので，L P ガス輸入業者にとっては毎年 
急速に負担が重くなって行くことになる。

な执, 本年 3 月頃輸入量の急激な減少のため，58年 度 (4月以降) の備蓄実行が困難となる輸入業者がで るのではないかという危惧が生じ，備蓄法に定められ ている緊急時の備蓄量減少の申請について業界で検討 が行われた。幸いにもスポット輸入の実施，需要削減 等の非常手段によって在庫量をキープできたので備蓄 量減少申請は 1 社も行わずにすんだ。だが，今後の輸 入状況次第ではこの問題が再燃してくることも予想さ れる。

\section{L P ガス車の車種拡大と商業車への普及}

従来からタクシー向けの L P ガス乗用車はすでに各 メーカーのアッセンブリーラインに乗っていたが， 57 年度はトヨタがカローラバン, 小型トラック（トヨタ ダイナ, トヨェース）のライン生産を開始した。タク シー向以外でL P ガス車がライン生産に乗ったのはこ れが初めてである。これでメーカー仕様車（乗用，貨 物を含む）15車種，改造可能車種26車種に達し，ほほ 陣容はととのった。自動車用 L P .ガス需要はここ数年 頭打ち状況を続けているだけに，L P ガススタンド業 界は新規ニーザー開拓に業界をあげて乗り出していた が，タクシー以外の一般車（主として小型貨物車等商 業車）への普及がようやく軌道に乗り始めた。L P ガ ススタンドの数の少なさ, 立地条件の悪さなど改善す べき問題は山積しているが，将来に明るい希望がもて るようになったものといえよう。

\section{5. バルク供給本格的に推進}

工業用，農水産用などのユーザーにローリーで小口 供給をしてあるくいわゆるバルク供給は法律上のネッ クもあってわが国では諸外国とちがってなかなか普及 されていなかったが，この推進は業界あげての希望で もあった。11月20日, 業界の自主基準として発効した 「日団協（日本 L P ガス団体連絡協議会） L P ガスバ ルク供給基準」は技術的基準および安全性の確認を骨 子とするもので，ほぼ10年にわたる業界の自主基準策 定の努力が実ったものである。な拉，同基準で定義す る L P ガスバルク供給方式とは「工業用消費者, 農業 用消費者などの敷地内に充填質量 3 千 $\mathrm{kg}$ 未満のバルク 容器を設置し，これに L P ガスバルク供給用タンク口 ーリーでL P ガスを充埧する方式」となっている。本 基準の制定，発効によって58年からは本格的なバルク 供給の年となろら。

\section{6. 流通実態調查, 配送センター実態調查}

通産省は57年度に L P ガス販売業実態調査（流通実 態調査と L P ガス供給・配送センター保安実態調查報
告書をまとめた。前者は 5 年ぶりに行われたもので, 調查対象は全販売事業所 $(44,370$ ) (回答率60.2\%), 調査内容は容器本数, 事業形態, 得意先軒数, 仕入れ 状況, 販売数量, 代金決済など22項目におよんでいる。 調査結果によると, 販売業規模の大型化, 従業員の高 齢化，ガス器具販売の沈帯などが目立つ。1 事業所当 りの平均消費者件数は569件, 月間販売量約 $12 \mathrm{t}$ となっ ている。一方, 供給配送センター実態調查はセンター と保安との関係を明らかにするため, 全国927ケ所のセ ンターを悉皆調查したもので回答率は79\%であった。 報告書の内容は，センタ一の運営形態，規模，配送業 務，保安点検業務などである。センターの利用で販売 店と消費者の対話が少なくなったとの指摘があった。

\section{5 ガス化に関する研究}

資源の有効利用の見地から各種有機物のガス化に関 する研究が行われている。原料としては, 石炭, チャ 一, オイルシェール, 石油留分, 重質油, バイオマス など数多くあるが，ここでは石炭，チャー以外の原料 のガス化について述べることにする。

低分子量炭化水素のガス化では, 水蒸気改質に関し ては, $\mathrm{Ca}$ アルネートや $\mathrm{Mg}$ アルミネートを含むア ルミナ担体付 $\mathrm{Ni}$ 触媒による $\mathrm{CH}_{4}$ からの水素製造 ${ }^{1)}$, 天然ガスからの合成ガス製造 ${ }^{2}, \mathrm{CH}_{4}$ の転化に特ける $\mathrm{Ni}$ 触媒上での 炭素析出 ${ }^{3)}$, 天然 ガス改質用の $\mathrm{NiO} /$ $\mathrm{Al}_{2} \mathrm{O}_{3}$ 触媒の工業的使用条件下での寿命 ${ }^{4}$, 天然ガス改 質用の $\mathrm{Ce}, \mathrm{Ni}$ 触媒の開発 ${ }^{5)}$, ブタンの $\mathrm{CH}_{4}$ への転化 ${ }^{6)}$, $\mathrm{C}_{2} \sim \mathrm{C}_{7}$ 炭化水素からの 水素製造 ${ }^{2}$ ，石油精製 ガスの $\mathrm{CH}_{4}$ ヘの転化 ${ }^{8)}$, 中圧連続式装置による LPG からの $\mathrm{SNG}$ 製造についての研究9)がある。また $\mathrm{NiO}-\mathrm{MgO}$ 触媒による天然ガス，LPG などの部分酸化 ${ }^{10)}$ につい ても検討された。

軽質留分のガス化では $\mathrm{Ni}$ 触媒によるn一ヘキサンな どの水蒸気改質 ${ }^{11)}$, ナフサの水蒸気改質における $\mathrm{Ni}$ / $\mathrm{Al}_{2} \mathrm{O}_{3}$ 触媒の熱処理の影響, 物理化学的特性沶よび $\mathrm{K}_{2} \mathrm{O}$ や $\mathrm{CaO}$ の添加効果 ${ }^{12)}$, エンジン効率の向上を目 的としたガソリンの水蒸気改質 ${ }^{13)}$ 执よび触媒の選択 ${ }^{14)}$ ナフサの水蒸気改質による合成ガスの製造 ${ }^{15)}$ ，芳香族 炭化水素の水素化による $\mathrm{CH}_{4}$ 生成 ${ }^{16) ~ 18), ~}$ 然料ガス製 造を目的とした Pt 触媒による灯油などの水蒸気改質 ${ }^{19)}$, $\mathrm{Ru}$ 触媒による炭化水素の水蒸気改質 ${ }^{20)}$, 都市ガ ス製造を目的とした燃焼と同時に水蒸気改質を行うサ 
イクリックプロセス ${ }^{21)}$ ，についての研究がある。その 他 $\mathrm{SNG}$ 製造を目的とした水蒸気改質用 $\mathrm{Ni} / \mathrm{Al}_{2} \mathrm{O}_{3}$ 触 媒の調製法 ${ }^{22) 23)}$ ，同じく水蒸気改質用の $\mathrm{CeO}_{2} / \mathrm{MgO}$ $\mathrm{Al}_{2} \mathrm{O}_{3}, \mathrm{Rh} / \mathrm{MgO}-\mathrm{Al}_{2} \mathrm{O}_{3}$ 触媒の調製法 ${ }^{24)}$, 都市ガス 製造用 $\mathrm{Ni}$ 触媒の活性劣化 ${ }^{25}$ についても検討された。

残油などの重質油のガス化では, 水蒸気改質に関し ては $\mathrm{CaO}$ などの塩基性触媒を用いガス化と同時に脱 硫む行うプロセス ${ }^{26)}$, 合成ガス ${ }^{27)}$ や燃料ガス製造 ${ }^{28)}$ 目的とした石油残渣のガス化，水素化分解残ピッチの ガス化に怙ける $\mathrm{K}_{2} \mathrm{CO}_{3}, \mathrm{~V}_{2} \mathrm{O}_{5}$ の添加効果 ${ }^{29)}, \mathrm{Al}_{2} \mathrm{O}_{3}$ 流 動床を用いた合成ガスの製造 ${ }^{30)}$ ，アルカリ土類金属一 アルミナ触媒を用いた燃料ガスの製造31)，アンガン鉱 石を用いたガス化 ${ }^{32)}$, 減圧残油のガス化触媒探索 ${ }^{33)}$, の研究が行われた。また原料を流動床でューク化し, これを水蒸気改質する方法 ${ }^{34)}$, 残油の部分酸化プロセ スで回収された炭素を水蒸気改質しさらにメタネーシ ョンにより然料ガスを製造するプロセス ${ }^{35)}$ ， も報告さ れている。部分酸化では発電・スチーム発生用の燃料 ガス製造 ${ }^{36)}$ ，シェル式ガス化プロセスによる合成ガス の製造37), 石油系コークのTexaco 液体燃料ガス化プ ロセスへの適用 ${ }^{38}$ についての研究が報告されている。 また部分酸化と同時に水蒸気改質を行う方法 ${ }^{39}$ につい ても報告されている。

その他合成ガス製造を併らフレキシューキング40), 気・液分の製造を目的とした残油の接触分解 ${ }^{41)}$, 炭化

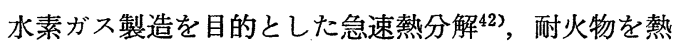
媒体として用いるタールサンドビチューメンや重油の 超フラッシュ式熱分解 ${ }^{43)}, \mathrm{Al}_{2} \mathrm{O}_{3}$ 流動床での熱分解・ 水蒸気改質・部分酸化を組久合わせた燃料ガス製造 ${ }^{44)}, \mathrm{Ni}, \mathrm{Ca}$ 塩触媒を用いたピッチコークの 水素化分 解による $\mathrm{CH}_{4}$ の製造 ${ }^{45)}$, 移動床での接触分解と析出コ 一クの炭酸カリウム触媒による水蒸気改質を組み合わ せた残油のガス化 ${ }^{46)}$ についても報告されている。

オイルシュールのガス化に関してはTiO2- $\mathrm{RuO}_{2}-\mathrm{Pt}$ 触媒を用い水の存在下で紫外線を照射してガス化する

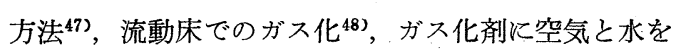
用い $\mathrm{Na}_{2} \mathrm{CO}_{3}$ 溶融塩でガス化する方法 ${ }^{49}$, 高硫黄含有 オイルシェールの水素化分解 ${ }^{50)}$, 熱分解によるオレフ インなどの石油化学原料ガスの製造 ${ }^{51)}$ が検討された。

廃木材やわらなどのバイオマス，都市廃棄物などの 有機廃棄物のガス化については数多くの研究が報告さ れている。水蒸気改質に関しては，酸素存在下での熱 分解・ガス化の反応速度論 ${ }^{52)}$, 熱分解を伴らガス化の メカニズム括よび装置 ${ }^{53)}$ ，固定床での接触および無触 媒ガス化の反応速度論54)，低発熱量ガス製造を目的と
したガス化 ${ }^{55)}$ ，メタノール合成原料の合成ガス製造 ${ }^{56)}$ 60)，太陽エネルギーを用いたガス化 ${ }^{61)}$ の研究が 報告 されている。部分酸化に関しては中発熱量ガスの製造 を目的とした流動床での酸素によるガス化 ${ }^{62) 63)}$ ，低発 熱量ガスの製造を目的とした流動床での空気によるガ

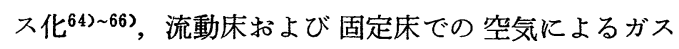
化 ${ }^{67)}$, 流動床での空気による接触ガス化 ${ }^{68)}$, 多段反応 装置によるガス化 ${ }^{69)}$ ，について報告されている。熱分 解に関しては燃料ガス製造を目的としたものが多い、70) 73)。その他固定床での熱分解, $\mathrm{O}_{2}, \mathrm{H}_{2} \mathrm{O}$ によるガス 化における反応温度と圧力の影響74), 低発熱量ガスや

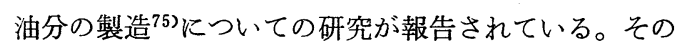
他ガス化発電プロセス ${ }^{76) 77) や ~} \mathrm{Cl}$ を含む原料に対し石 灰を添加し移動床でガス化するプロセス ${ }^{78)}$, Winkler システムなどの木材への適用 ${ }^{79)}$, 産業廃棄物からの然

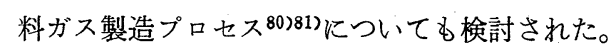

以上の他に石炭・チャー以外の固体炭素質物質のガ ス化触媒に関寸る研究も行われている。 $\mathrm{K}_{2} \mathrm{CO}_{3}$ を用い た水蒸気改質の反応速度論 ${ }^{82) 83)}$, リン酸ナトリウム溶 融塩を用いたガス化 ${ }^{84)}$ ，ガス化剤に $\mathrm{H}_{2} \mathrm{O}, \mathrm{CO}_{2}$ を用 いた Pt 触媒存在下での反応速度論 ${ }^{85)}$ ，およびアルカ リ金属塩や貴金属の添加効果 ${ }^{86) 87)}, \mathrm{Li}$ 塩の添加効果 作用機構 ${ }^{88)}$ ，アルカリ金属化合物を用いた水蒸気改質 による $\mathrm{CH}_{4}$ 製造89)などである。

\section{文 献}

1) Denbnoveskaya, E. N., et al., Katal. Konversiya Uglevodorodov, 5, 86 (1980)

2) Marsch, H.D., et al., Hydrocarbon Process., 61, 101

3) Khomenko, A. A., et al., Katal. Konversiya Uglevodorodov, 5, 10 (1980)

4) Denbnovetskaya, E. N., et al., ibid., 5, 64 (1980)

5) Twigg, M. V., EP 45, 126

6) Kosyagin, V.G., et al., Katal. Konversiya Uglevodrodov, 6, 51 (1981)

7) Abidov, M., et al., Katal. Konversiya Uglevodorodov, 5, 84 (1980)

8) Chastukhin, V.V., et al., ibid., 6, 55 (1981)

9）日本海ガス，他，日本ガス協会誌，35，(6)，37

10) Osaka Gas Co., Ltd., 公開8228, 189

11) Nasirov, P., et al., Katal. Konversiya Uglevodorodov., 6, 23 (1981)

12) Srivastava, A.K., et al., Fert. Technol., 17, (3-4), 170 (1980)

13) Suzuki Motor Co., Ltd., 82 07, 198

14) Chalyuk, G.I., et al., Katal. Konversiya Uglevodorodov, 6, 63 (1981)

15) Marschner, F., et al., Hydrocarbon Process., 
61, (4), 176

16) Gräber, W.D., et al., Fuel, 61, (6), 499

17) Gräber, W.D., et al., ibid., 61, (6), 505

18) Gräber, W.D., et al., ibid., 61, (6), 510

19) Matsuphita Electric Industrial Co., Ltd., 公 開, 81, 167, 786

20) Osaka Gas Co., Ltd., 公開, 8204, 232

21) Hitachi Shipbuilding and Engineering Co., Ltd., 公開, 8231, 988

22) Sambrook, R.M., et al., EP 44, 118

23) Sambrook, R. M., et al., EP 44, 117

24) Toyota Central Research and Development Laboratories, Inc., 公開, 8224, 639

25) Jovanovic, M., et al., Hem. Ind., 36, (1), 22

26) Nippon Steel Corp., 公開, 82 23, 682

27) Nazarkina, E. B., Sb. Nauchn. Tr.-Vses. Nauchno-Issled, 39, 114 (1981)

28) Karzhev, N. A., ibid., 39, 147 (1981)

29) Sekhar, M. V.C., et al., Fuel Process Technol., 6, (1)

30) Agency of Industrial Sciences and Technology，公開，81，161，492

31) Toyo Engineering Corp., 公開, 82, 65, 780

32) Kandelaki, A.Sh., et al., Neftepererab. Neftekhim., 12, 5 (1981)

33) Kyushu Refractories Co., Ltd., 公開, 82, 45,344

34) Exxon Research and Engineering Co., Neth, Appl. NL 8104, 078

35) Osaka Gas Co., Ltd., 公開, 82 96, 085

36) Derbaremdiker, M.I., et al., Sb. Nauchn. Tr.-Vses. Nauchno-Issled, 39, 131 (1981)

37) Madsack, H. J., Hydrocarbon Process., 61, (7), 169

38) Stone and Webster Engineering Corp., DE 82007922

39) Nikolaev, N. I., et al., Sb. Nauchn. Tr.-Vses. Nauchno-Issled, 39, 120 (1981)

40) Allan, D.E., et al., Natl. Pet. Refiners Assoc. AM-82-46

41) Soskind, D.M., et al., Khim. Tekhnol. Topl. Masel., (10), 5

42）鈴木俊光，他，燃協誌，61，(662），397

43) Bergougnou, M.A., et al., Proc. CIC Coal Symp. 64th, 2, 523 (1981)

44）千代田化工(侏)，公開，82117，587

45) Nishiyama, Y., et al., 公開, 81157, 493

46) Ternan, M., et al., CA 1, 123, 774

47) Hayato, N., Braz. BR 8106,361

48) Martins, A., et al., Fiz. Aerodispersnykh Sist., 20, 85 (1980)

49) Susic. M., et al., Glas-Srp. Akad. Nauka Umet., Od. Prir.-Mat. Nauka, 48, 27 (1981)

50) Loginova, V.E., et al., Issled. v Obl. Kompleks. Energotekhn. Is polz. Topliva. Saratov, 23

51) Mester, Z.C., et al., Prepr. Pap. Am.
Chem. Soc. Div.Fuel Chem., 27, 224

52) Divry, A., et al., Comm. Eur. Communities, EUR 7091 (1981)

53) Lucas, J., et al., Comm. Eur. Communities, EUR 7559

54) Kumar, A., et al., Proc.-Bioenergy R \& D Semin. 3rd. 231 (1981)

55) Hos, J. J., et al., Comm, Eur. Communities EUR 7091 (1981)

56) Mudge, L.K., et al., An.-Congr. Bras. Energ., 2nd, A. 335 (1981)

57) Graham, R., Chem. Can., 34, (3), 16

58) Lindner, C., JUEL-CONF-46, 214 (1981)

59) Nitschke, E., ibid., JUEL-CONF-46, 232 (1981)

60) Robert, R. J., et al., PNL-SA-9174

61) Lede. J., et al., Recherche, 13, (134), 786

62) Chrysostome, G., EUR 7091, Energy Biomass, Conf., lst, 594 (1981)

63) Burnett, T.C., et al., Proc.-Bioenergy R \& D Semin. 2nd, 233 (1980)

64) Flanigan, V.J., et al., Energy Biomass Wastes 6th, 645

65) Guttmann, F.W., et al., DE 3, 042, 200

66) Pillard, J.C., et a.l., BR 8200,593

67) Garkisch, A., et al., JUEL-CONF-46, 131, (1981)

68) Lian, C.K., et al., Ind. Eng. Chem. Process Des. Dev., 21, (4), 699

69) Hartmann, T.A., et al., DE 3103255

70) McMullen, F. G, , US 4, 321, 150

71) Chornet, E., et al., Proc.-Bioenergy R \& D Semin. 2nd, 137 (1980)

72) Both, A., BR 8005, 229

73) Reed, T.B., et al., Biotechnol. Bioeng. Symp., 11, 137 (1981)

74) Dubois, P., et al., Energy Biomass Wastes, 6 th, 763

75) Skelley, W.N., et al., ibid., 6th, 665

76) Wild, D., et al., Proc.-Bioenergy R \& D Semin. 3rd, 337 (1981)

77) Zerbin, H., JUEL-CONF-46, 102 (1981)

78) Hos, J.J., et al., PT-Procestech., 37, (9), 70

79) Zagatto, A. J. A. G., Energia, 3, (16), 44 (1981)

80) Hummelsiep, H., et al., BMFT-FB-T82-118

81) Hummelsiep, H., et al., BMFT-FB-T82-117

82) Mims, C. A., et al., Prep. Pap. Am. Chem. Soc. Div. Fuel Chem., 25, (3), 258 (1980)

83) Mims, C. A., et al., ibid., 25, (3), 263 (1980)

84) Siddoway, M. A., Avail. Univ. Microfilms Int., Order No. DA8216041

85) Holstein, W.L., et al., J. Catal., 75, (2), 337

86）稲川郁夫，他，触媒討論会 (A)予稿集，50th, 102

87）富士川計吉, 他, 触媒討論会 (A) 予稿集, 50th, 104

88) McKee, D. W., Carbon, 20, (1), 59

89) Cabrera, A.L., et al., J. Calal., 75, (1), 7 